\title{
A Review of Lithium-Ion Battery Fire Suppression
}

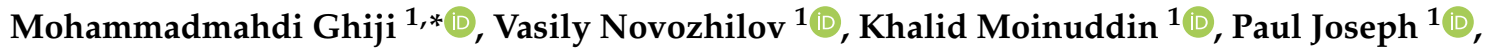 \\ Ian Burch $^{2}$, Brigitta Suendermann ${ }^{2}$ (D) and Grant Gamble ${ }^{2}$ (D) \\ 1 Institute of Sustainable Industries and Liveable Cities, Victoria University, Melbourne, VIC 3030, Australia; \\ Vasily.Novozhilov@vu.edu.au (V.N.); Khalid.Moinuddin@vu.edu.au (K.M.); Paul.Joseph@vu.edu.au (P.J.) \\ 2 Maritime Division, Defence Science \& Technology Group, Melbourne, VIC 3207, Australia; \\ Ian.Burch@dst.defence.gov.au (I.B.); Brigitta.Suendermann@dst.defence.gov.au (B.S.); \\ Grant.Gamble@dst.defence.gov.au (G.G.) \\ * Correspondence: Mohammadmahdi.ghiji@vu.edu.au
}

Received: 5 August 2020; Accepted: 28 September 2020; Published: 1 October 2020

\begin{abstract}
Lithium-ion batteries (LiBs) are a proven technology for energy storage systems, mobile electronics, power tools, aerospace, automotive and maritime applications. LiBs have attracted interest from academia and industry due to their high power and energy densities compared to other battery technologies. Despite the extensive usage of LiBs, there is a substantial fire risk associated with their use which is a concern, especially when utilised in electric vehicles, aeroplanes, and submarines. This review presents LiB hazards, techniques for mitigating risks, the suppression of LiB fires and identification of shortcomings for future improvement. Water is identified as an efficient cooling and suppressing agent and water mist is considered the most promising technique to extinguish LiB fires. In the initial stages, the present review covers some relevant information regarding the material constitution and configuration of the cell assemblies, and phenomenological evolution of the thermal runaway reactions, which in turn can potentially lead to flaming combustion of cells and battery assemblies. This is followed by short descriptions of various active fire control agents to suppress fires involving LiBs in general, and water as a superior extinguishing medium in particular. In the latter parts of the review, the phenomena associated with water mist suppression of $\mathrm{LiB}$ fires are comprehensively reviewed.
\end{abstract}

Keywords: lithium-ion battery; thermal runaway; fire suppression; water mist

\section{Introduction}

The first lithium-ion battery (LiB) was proposed by Yoshino in 1985, based on earlier research by Whittingham [1] in the 1970s, and Goodenough et al. [2,3] during the 1970s-1980s. LiBs became commercially available in 1991 [4] and have become the battery chemistry of choice for electronic devices, transportation and energy storage [5]. LiBs offer great energy and power density, light weight and a long lifespan [6,7] when compared to older battery chemistries, as listed in Table 1 . It can be seen that LiB technology has a high energy density and is ideal for cyclic applications. It is smaller and lighter compared to conventional lead-acid or Nickel Cadmium batteries. These advantages are encouraging for the replacement of conventional battery technologies with lithium-ion [8]. However, if the internal temperature of a $\mathrm{LiB}$ increases beyond its operating range, by external or internal means, components of the battery may become unstable and tend to generate additional heat. If this heat does not dissipate, the battery temperature will elevate further, thereby accelerating the process of heat release. This process is called thermal runaway. $\mathrm{LiB}$ chemistry differs from battery technologies such as lead-acid, nickel-cadmium, zinc bromide and alkaline by using a flammable organic electrolyte, presenting a fire risk during thermal runaway process that needs to be addressed to ensure a safe 
operating environment. Although fire can be extinguished by many methods, the effects of thermal runaway are more difficult to manage and continued cooling is required.

Table 1. Characteristics of different battery technologies [9]. Response time is the time to deliver maximum power output over a specific time, with $\mathrm{h}=$ hours; $\mathrm{min}=$ minutes; $\mathrm{ms}=$ milliseconds; $\mathrm{s}=$ seconds; $\mathrm{NA}=$ not applicable.

\begin{tabular}{|c|c|c|c|c|c|c|c|c|c|}
\hline & $\begin{array}{l}\text { Lifetime } \\
\text { Years } \\
\text { (Cycles) }\end{array}$ & $\begin{array}{c}\text { Power } \\
\text { Density } \\
\mathrm{Wkg}^{-1} \\
\left(\mathbf{k W m}^{-3}\right)\end{array}$ & $\begin{array}{c}\text { Energy } \\
\text { Density } \\
\text { Whkg }^{-1} \\
\left(\mathrm{kWhm}^{-3}\right)\end{array}$ & $\begin{array}{l}\text { Discharge } \\
\text { Time }\end{array}$ & $\begin{array}{l}\text { Recharge } \\
\text { Time }\end{array}$ & $\begin{array}{c}\text { Response } \\
\text { Time }\end{array}$ & $\begin{array}{l}\text { Operating } \\
\text { Temperature } \\
\left({ }^{\circ} \mathrm{C}\right)\end{array}$ & $\begin{array}{l}\text { Self-Discharge } \\
\text { (\%/day) }\end{array}$ & $\begin{array}{l}\text { Critical } \\
\text { Voltage/Cell } \\
\text { (V) }\end{array}$ \\
\hline $\begin{array}{l}\text { Lithium-ion } \\
\text { battery }\end{array}$ & $\begin{array}{c}8-15 \\
(500-6000)\end{array}$ & $\begin{array}{c}230-340 \\
(1300-10000)\end{array}$ & $\begin{array}{c}100-250 \\
(250-620)\end{array}$ & $\min -\mathrm{h}$ & $\min -\mathrm{h}$ & $20 \mathrm{~ms}-\mathrm{s}$ & -10 to 50 & $0.1-0.3$ & 3 \\
\hline $\begin{array}{c}\text { Lead-acid } \\
\text { battery }\end{array}$ & 3-15 (2000) & $\begin{array}{c}75-300 \\
(90-700)\end{array}$ & $30-50(75)$ & $\min -\mathrm{h}$ & $8-16 \mathrm{~h}$ & $5-10 \mathrm{~ms}$ & -10 to 40 & $0.1-0.3$ & 1.75 \\
\hline $\begin{array}{c}\text { Advanced } \\
\text { lead-acid } \\
\text { battery }\end{array}$ & 3-15 (3000) & $\begin{array}{c}75-300 \\
(90-700)\end{array}$ & $30-50(75)$ & $\min -\mathrm{h}$ & $8-16 \mathrm{~h}$ & $5 \mathrm{~ms}$ & -10 to 40 & $0.1-0.3$ & 2 \\
\hline $\begin{array}{l}\text { Nickel-cadmi } \\
\text { battery }\end{array}$ & $\begin{array}{l}15-20 \\
(2500)\end{array}$ & $\begin{array}{l}150-300 \\
(75-700)\end{array}$ & $\begin{array}{l}45-80 \\
(<200)\end{array}$ & $\mathrm{s}-\mathrm{h}$ & $1 \mathrm{~h}$ & $\mathrm{~ms}$ & -40 to 45 & $0.2-0.6$ & 1 \\
\hline $\begin{array}{c}\text { Zinc } \\
\text { bromide } \\
\text { flow } \\
\text { battery }\end{array}$ & $\begin{array}{c}5-10 \\
(300-1500)\end{array}$ & $\begin{array}{l}50-150 \\
(1-25)\end{array}$ & $\begin{array}{l}60-80 \\
(20-35)\end{array}$ & $\mathrm{s}-10 \mathrm{~h}$ & $4 \mathrm{~h}$ & $<1 \mathrm{~ms}$ & 10 to 45 & $0-1$ & $0.17-0.3$ \\
\hline $\begin{array}{l}\text { Vanadium } \\
\text { redox flow } \\
\text { battery }\end{array}$ & $\begin{array}{c}10-20 \\
(13-103)\end{array}$ & NA $(0.5-2)$ & $75(20-35)$ & $\mathrm{s}-10 \mathrm{~h}$ & $\min$ & $<1 \mathrm{~ms}$ & 0 to 40 & $0-10$ & $0.7-0.8$ \\
\hline
\end{tabular}

This paper reviews the processes associated with LiB thermal runaway and fire suppression. Extinguishing agents are examined and the mechanisms associated with fire suppression are presented.

\section{Lithium-Ion Battery Components}

A lithium-ion cell consists of a cathode, an anode, separator, and electrolyte. The anode and cathode materials are deposited onto copper and aluminium foil current collectors, respectively. The electrolyte enables the movement of lithium ions between the electrodes, while the separator fits between the anode and cathode preventing shorting between the two electrodes but permitting ion transfer. During the discharge reaction, lithium ions move from the anode and insert into the voids between layers of cathode crystals (the process named intercalation). Upon charging, lithium ions move from the cathode on the positive side of the battery and insert into the anode. The LiB components and processes are illustrated in Figure 1. During the initial charge, intercalated lithium ions react immediately with the solvent of the electrolyte and form a passivation layer on the anode, the Solid-Electrolyte Interphase (SEI), which is permeable to lithium ions but not to the electrolyte [7]. The stability of the SEI is a determining factor of LiBs' safety and life.

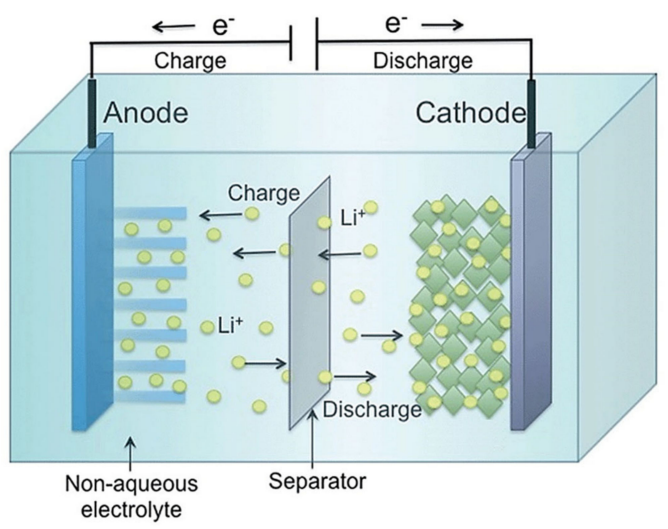

Figure 1. The principle of the lithium-ion battery (LiB) showing the intercalation of lithium-ions (yellow spheres) into the anode and cathode matrices upon charge and discharge, respectively [10]. 
The details of each battery component are provided in the following sections.

\subsection{Cathode}

The cathode composition gives the name to the type of LiB. Lithium metal oxides such as Lithium Cobalt Oxide (LCO), Nickel Cobalt Aluminium Oxide (NCA), Lithium Cobalt Phosphate (LCP), Nickel Cobalt Manganese Oxide (NCM), Lithium Manganese Oxide (LMO), Lithium Iron Phosphate (LFP), Lithium Iron Fluorosulphate (LFSF) and Lithium Titanium Sulphide (LTS) have been used as cathode materials owing to their high capacity for lithium intercalation and compatible chemical and physical properties (e.g., for the reversibility of the intercalation reactions) necessary for lithium ion transport. Figure 2 presents cell specific capacity and average discharge potential of a series of cathode materials [11]. LCO, NCA and NCM all have a layered structure with high energy density at the cost of lower thermal stability, and contain expensive cobalt. LMO has a spinel-like structure, great thermal stability and high voltage but relatively low capacity. LFP has a stable olivine structure and has attracted significant interest [12-15] due to low cost as it does not contain cobalt, has high average voltage and a low susceptibility to thermal runaway compared to NCM and LCO, providing a good balance between performance and safety [16-18]. To date, cathode materials with high capacity and voltage such as nickel- [19-24], manganese- [25] and lithium-rich [19,25-31] materials, carbon-coated LFP nanospheres [32] and vanadium pentoxide [33] have been recognized. Higher contents of nickel and lithium increase the specific capacity of the cathode material but decrease thermal stability. The thermal instability of LiBs have been systematically characterised using synchrotron-based X-ray techniques [34,35]. The outcomes of these investigations provided fundamental understanding and guidance which is vital to develop safer batteries with a high energy density.

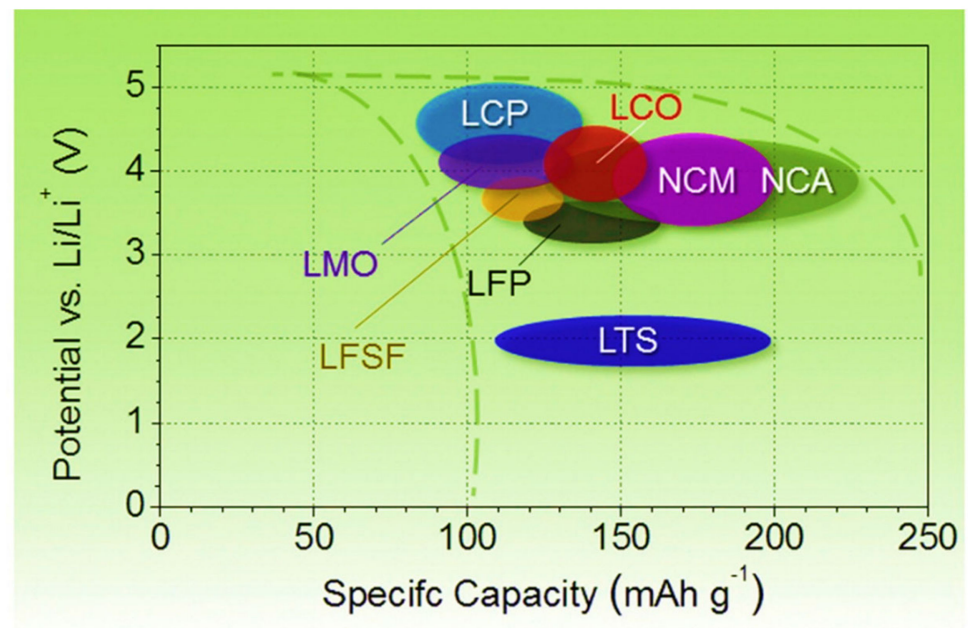

Figure 2. Average discharge potentials and specific capacity of common cathodes [11].

\subsection{Anode}

The most common material used for LiB anodes is graphite due to its high negative potential. Other materials such as lithium titanate and silicone operate at lower negative voltages reducing the energy and power density, making them less practical except for fast charging devices [36] and fixed energy storage where the importance of energy density is less significant [37]. Lithium titanate and silicone enable lithium ions to travel more readily which decreases the internal resistance and reduces battery heating compared to the graphite anode [38]. Studies to identify new materials for anodes with higher capacity and voltage have been undertaken. Materials such as silicon [39,40], tin [41], antimony [42], germanium [43,44], silicon oxide [45], transition metal oxide: $\mathrm{MO}$ (where M is cobalt, nickel, copper or iron) [44,46], ultra-thin graphene nanosheets [47], and layered boron-nitrogen-carbon-oxygen material with adjustable composition [48] have been tested. 
In the development of new anode materials, properties including capacity retention, conductivity, volume expansion, dendrite formation, and stability of the SEI layer should be considered before commercialisation [49].

\subsection{Separator}

In LiBs, the cathode and anode are separated by a porous membrane called the separator [50]. The separator is a crucial component in a lithium-ion cell, it prevents electrical short circuits between the two electrodes but allows transport of lithium ions between the electrodes [51]. The most popular separator materials for LiBs with organic electrolytes are made of microporous polyolefin films such as polyethylene (PE), polypropylene (PP), or laminates of polyethylene and polypropylene offering outstanding chemical stability, mechanical properties, and acceptable cost [51]. The low melting point of polyolefins $\left(135^{\circ} \mathrm{C}\right.$ for $\mathrm{PE}$ and $165^{\circ} \mathrm{C}$ for PP) qualifies their utilisation as a thermal fuse to shut down the cell by losing porosity and permeability if an over-temperature condition occurs [51]. New separator designs such as ceramic composite (frequently alumina and silica) [52-55] and multilayered ceramic composite (with a shutdown feature through different phase change layers) [56-58] have been established with improved mechanical strength and thermal stability. Other separator materials and designs include polyester fibre non-woven membranes [56], silica/polyvinylidene fluoride porous composite matrix [59], porous-layer-coated polyimide nanofiber [60] and polyformaldehyde/cellulose nanofibre blends [61].

\subsection{Electrolyte}

The electrolyte infills the space between the separator and electrodes. The electrolyte formulation in LiBs is dependent on the electrode materials and operating conditions [36]. The typical electrolyte for LiBs is made of a flammable carbonate-based organic solvent such as ethylene carbonate (EC), dimethyl carbonate (DMC), diethyl carbonate (DEC) and ethyl methyl carbonate (EMC), and/or propylene carbonate (PC) [62], with additives including lithium hexafluorophosphate $\left(\mathrm{LiFP}_{6}\right)$, lithium hexafluoroarsenate monohydrate $\left(\mathrm{LiAsF}_{6}\right)$, lithium perchlorate $\left(\mathrm{LiClO}_{4}\right)$, and lithium tetrafluoroborate $\left(\mathrm{LiBF}_{4}\right)$ to improve cycling [63]. New electrolytes aim to mitigate the fire risk associated with conventional electrolytes using more stable lithium salts [64,65], additives [66-74], ionic liquid [75-77], non-flammable solvents [78,79], synthesized aqueous electrolytes [80,81], polymer electrolytes [82-84] and/or solid-state electrolytes [66,85-87].

The performance, cost and safety of LiBs depend on their electrochemistry. For example, a lithium-ion cell with a LCO positive and a graphite negative electrode delivers high voltage and energy density but presents a higher thermal runaway risk which may lead to cell rupture, venting, ignition of the electrolyte and fire [88].

\section{Lithium-Ion Battery Systems}

Lithium-ion cells are commercially available in button, cylindrical, pouch and prismatic designs as illustrated in Figure 3.

To supply the desired power and energy from a battery system (an energy storage system), the cells are connected in parallel to increase the capacity or in series to raise the voltage.

A battery system usually consists of a number of battery packs, which are made of multiple battery modules, each containing a number of cells with series and/or parallel configuration as depicted in Figure 4. 

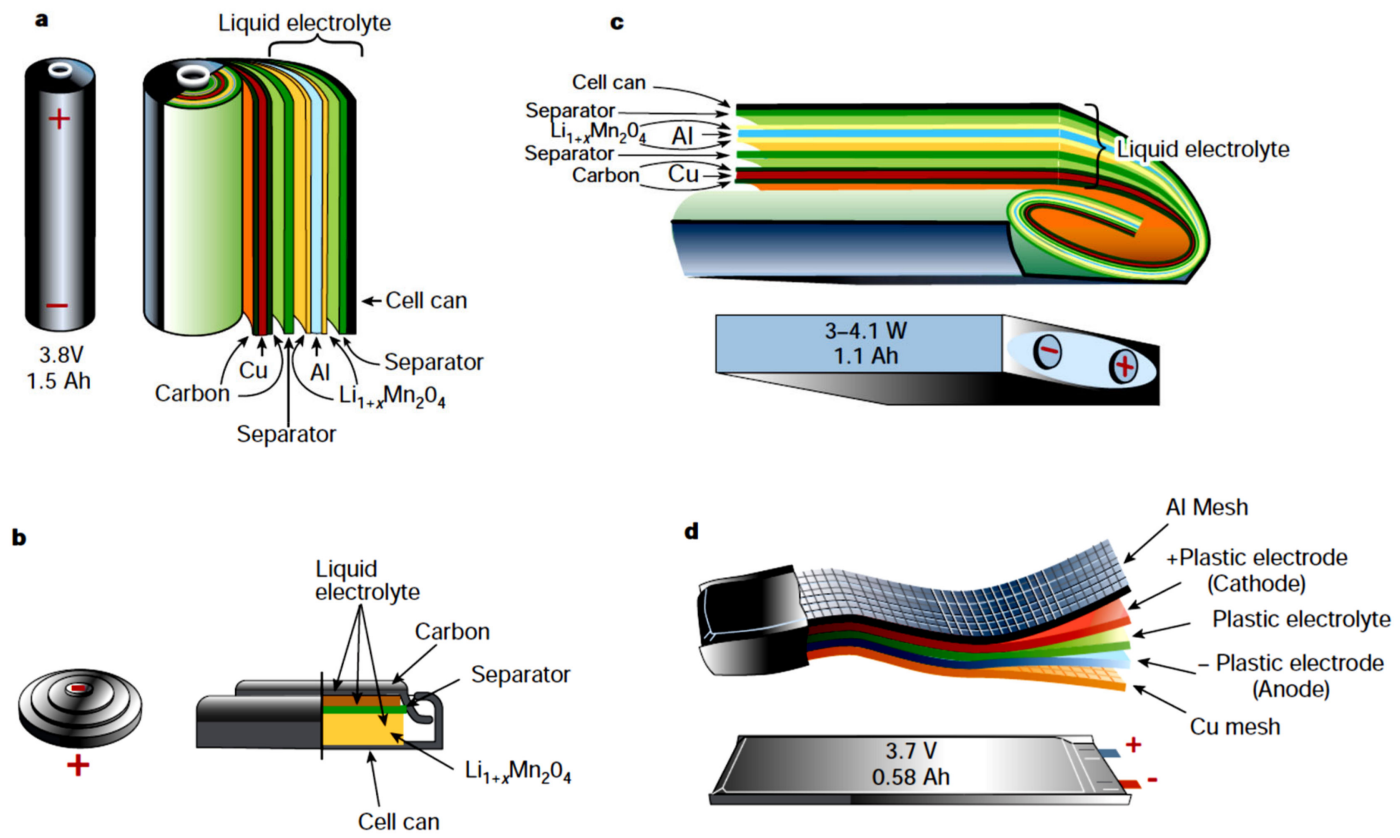

Figure 3. Lithium-ion cell designs and structures [7]. (a-d) show cylindrical, button, prismatic, and pouch cells, respectively.

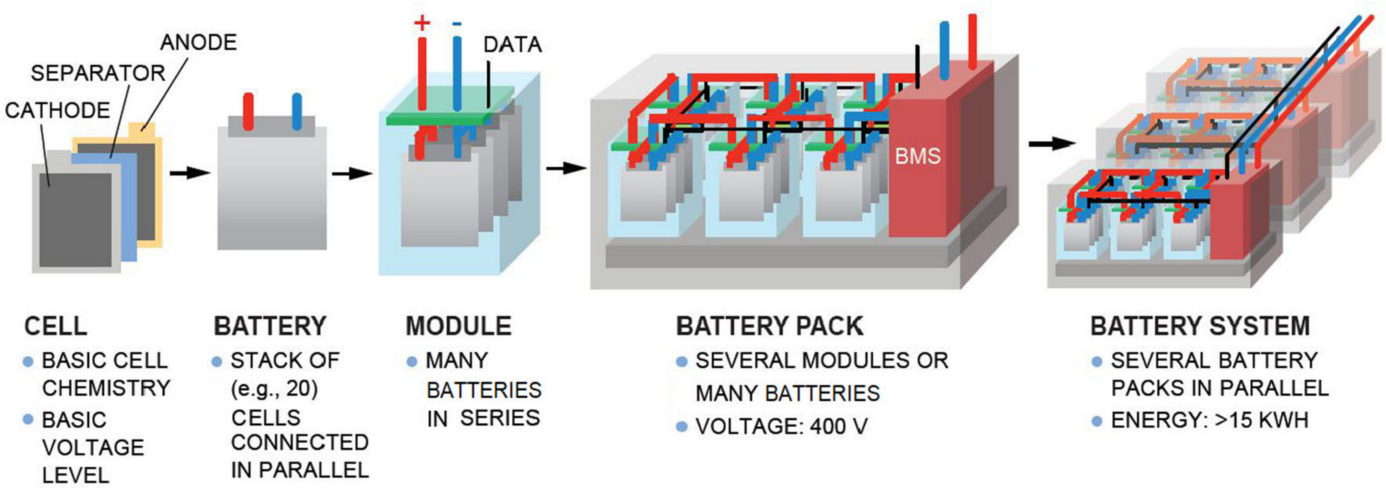

Figure 4. Packaging of typical battery systems. Image is adopted from [89].

\section{Thermal Runaway and Fire}

Despite the extensive usage of LiBs in energy storage applications, they are susceptible to thermal runaway and fire [90] which is the primary safety concern when used in hybrid electric vehicles (HEVs) [91,92], electric vehicles (EVs) [91,93-96], aeroplanes and submarines [97,98]. The LiB systems used in these applications consist of multi-cell packs and modules where thermal runaway in a single cell can initiate thermal runaway in adjacent cells and consequently compromise the integrity of the entire battery system $[99,100]$.

The conditions which may lead to thermal runaway and fire in LiBs fall into four categories [101]:

- Electrical abuse (over-charging/discharging) [36,102-106]: Over-charging or discharging to voltages beyond the manufacturers specified charge window can cause lithium plating, or dendrite formation, on the anode. Over time, this may pierce the separator causing a short circuit between electrodes and lead to thermal runaway.

- Thermal abuse (over-temperature) [88,90,107-109]: Internal temperature in the $90-120^{\circ} \mathrm{C}$ range will cause the SEI layer within a $\mathrm{LiB}$ to decompose exothermically. At temperatures above $200^{\circ} \mathrm{C}$, the hydrocarbon electrolyte can decompose and release heat. 
- Mechanical abuse (penetration, pinch, and bend) $[93,110]$ : Mechanical abuse, usually caused by external mishap to the LiB such as car crash or during installation, can result in electrical shorting between the electrodes, via the electrolyte, producing localised heating.

- Internal short circuit (ISC) [94]: An ISC occurs due to the failure of the separator, allowing contact between the cathode and anode via the electrolyte. This can happen due to any of the above abuse conditions, or as a result of a manufacturing fault.

Any of these abuse conditions may result in an increase in the internal temperature of the cell, which in turn can initiate exothermic reactions such as SEI decomposition. This can lead to a loss of protection to the anode such that the fluorinated binder within the anode can react exothermically with lithiated carbon, exothermic reactions between the intercalated lithium and electrolyte, or cathode decomposition giving off oxygen enabling combustion with the electrolyte [88]. The heat released increases the temperature of the cell and initiates additional reactions, which generate extra heat, creating a heat-temperature reaction loop. This loop results in high internal temperatures and pressures which can lead to cell swelling, cell rupture, gas venting (sometimes violent) and possibly fire [94].

At temperature above the normal operating range, electrochemical reaction processes, many of which occur simultaneously are very complex. To exemplify, Figure 5 overviews the thermal runaway processes of LCO/graphite. At temperature above $69^{\circ} \mathrm{C}$, the SEI start to decompose followed by exothermic reactions between anode and electrolyte, and anode materials and the binder, separator meltdown, electrolyte decomposition, and reactions between the cathode material and electrolyte [111].

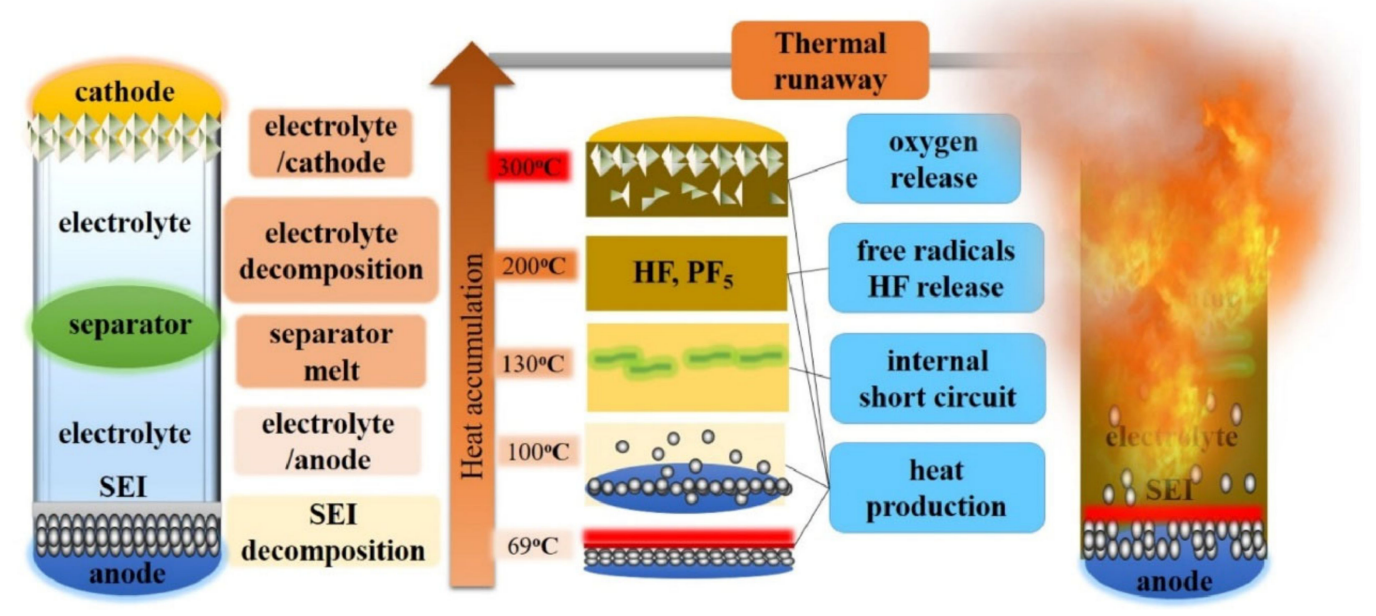

Figure 5. A schematic of thermal runaway processes in lithium cobalt oxide (LCO)/graphite cell [66].

During thermal runaway in a $\mathrm{LiB}$, the electrolyte and separator may significantly contribute to the heat released in the presence of oxygen through their ignition and burn properties. The electrolyte and separator have low mass in a LiB but high effective heat of combustion, and account for approximately $80 \%$ of the heat release in a LiB fire $[112,113]$. As shown in Figure 6 , the effective heat of combustion for a commercial LMO pouch cell has been measured as $4.03 \pm 0.34 \mathrm{MJ} \mathrm{kg}^{-1}$ with the electrolyte and separator contributing up to 1.92 , and $1.34 \mathrm{MJ} \mathrm{kg}^{-1}$, respectively [112]. 
(a)

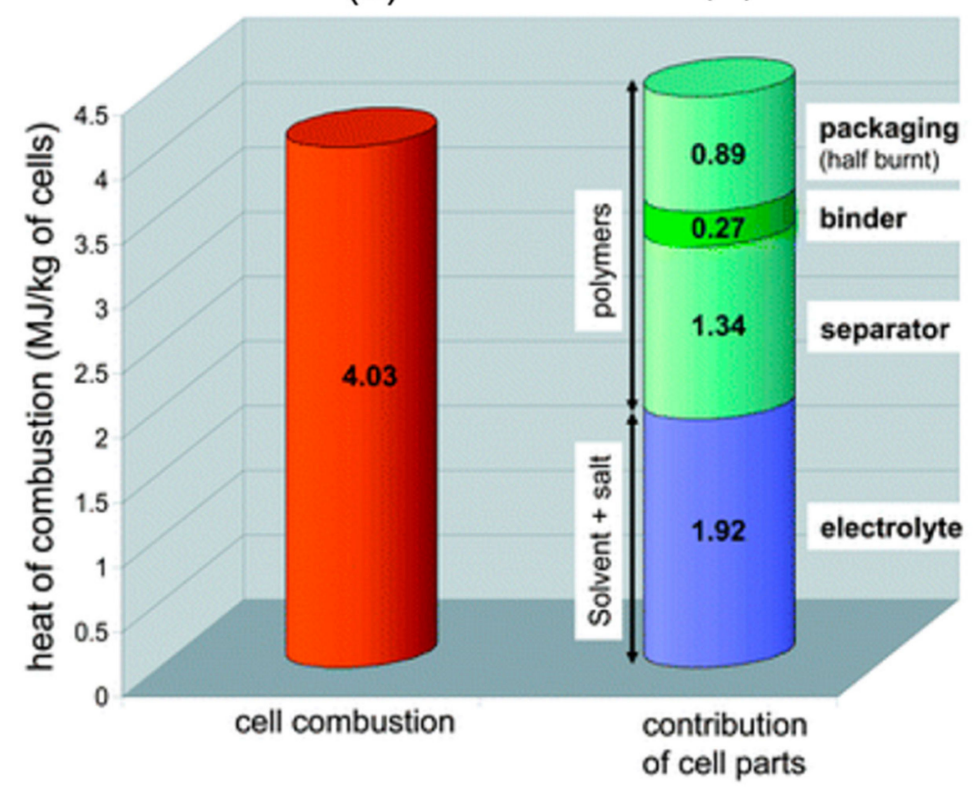

Figure 6. (a) The total heat of combustion measured through the experimentations. (b) heat of combustion of battery components determined by thermodynamic calculations. Adopted from [112].

The thermal runaway process poses serious fire safety implications [114], especially for confined spaces such as in passenger vehicles, aeroplanes and submarines [97]. The likelihood and severity of fire risks associated with LiBs were presented over the past two decades where more than 300 fires or fire-related incidents with 40 fatalities reported [97]. Table 2 lists some of the LiB thermal runaway and fire incidents reported over the last two decades [94,111]. The LiB fire incidents are widespread, from small consumer electronics such as mobile phones to large EVs and airplanes. Potential causes of the LiB accidents and mechanisms leading to the separator tearing, piercing and collapsing, subsequently internal short circuit, and possibly thermal runaway are presented in Figure 7. The numerous accidents have demonstrated that LiB technology is a serious safety concern, which has obliged governments to enforce new regulations and fire protection technologies for transport and storage of these devices $[93,115]$.

Table 2. Selected LiBs fire and explosion accidents [94,111].

\begin{tabular}{ccccc}
\hline No. & Date & Location & Incident Description & Possible Cause \\
\hline 1 & March 2019 & $\begin{array}{c}\text { Brabant, } \\
\text { Netherlands }\end{array}$ & $\begin{array}{c}\text { A HEV (BMW i8 plug-in hybrid) } \\
\text { started to smoke in a showroom }\end{array}$ & Unknown. \\
\hline 2 & January 2019 & Adelaide, Australia & $\begin{array}{c}\text { Electric road bike exploded and } \\
\text { caught fire }\end{array}$ & Internal short circuit \\
\hline 4 & January 2019 & Florida, USA & An EV (Tesla Model S) caught fire & Crash. \\
\hline 5 & June 2018 & Vancouver, Canada & $\begin{array}{c}\text { e-cigarette caused fire in the } \\
\text { baggage compartment of a } \\
\text { WestJet flight, making an } \\
\text { emergency landing }\end{array}$ & Unknown. \\
\hline 6 & September 2016 & California, USA & $\begin{array}{c}\text { An EV (Tesla Model X) caught fire } \\
\text { after crashing into a garage }\end{array}$ & $\begin{array}{c}\text { Crash deformed the battery } \\
\text { modes initiating short circuit, } \\
\text { outgassing and fire. }\end{array}$ \\
\hline
\end{tabular}


Table 2. Cont.

\begin{tabular}{|c|c|c|c|c|}
\hline 7 & August 2016 & Paris, France & $\begin{array}{l}\text { An EV (Tesla Model S) car caught } \\
\text { fire during a promotional tour }\end{array}$ & Unknown. \\
\hline 8 & July 2106 & Rome, Italy & An EV police car caught fire. & Unknown. \\
\hline 9 & July 2106 & Nanjing, China & $\begin{array}{l}\text { The battery pack of an EV (bus) } \\
\text { caught fire after heavy rain. }\end{array}$ & $\begin{array}{c}\text { Water immersion causing short } \\
\text { circuit. }\end{array}$ \\
\hline 10 & June 2106 & Beijing, China & An iEV5 caught fire. & $\begin{array}{l}\text { Overheating by loose wire } \\
\text { connection. }\end{array}$ \\
\hline 11 & June 2106 & Shenzhen, China & $\begin{array}{l}\text { An EV (Wuzhou Dragon) bus } \\
\text { caught fire. }\end{array}$ & $\begin{array}{l}\text { A short circuit created by wire } \\
\text { deterioration. }\end{array}$ \\
\hline 12 & January 2016 & Gjerstad, Norway & $\begin{array}{c}\text { An EV (Tesla Model S) car caught } \\
\text { fire during fast charging at a } \\
\text { fastcharger Station. }\end{array}$ & Short circuit while charging. \\
\hline 13 & September 2015 & Hangzhou, China & $\begin{array}{l}\text { The battery pack of an HEV bus } \\
\text { caught fire. }\end{array}$ & Unknown. \\
\hline 14 & April 2015 & Shenzhen, China & $\begin{array}{l}\text { An EV (Wuzhou Dragon) bus } \\
\text { caught fire while charging in a } \\
\text { carpark. }\end{array}$ & $\begin{array}{c}\text { The Battery Monitoring System } \\
\text { failed to stop charging, the battery } \\
\text { pack was overcharged. }\end{array}$ \\
\hline 15 & October 2013 & Tennessee, USA & $\begin{array}{l}\text { An EV (Tesla Model S) car } \\
\text { collided with metal objects at } \\
\text { highway and caught fire. }\end{array}$ & $\begin{array}{l}\text { Short circuit induced by piercing } \\
\text { and deformation of the battery } \\
\text { pack after colliding with the metal } \\
\text { objects. }\end{array}$ \\
\hline 18 & January 2013 & Takamatsu, Japan & $\begin{array}{l}\text { The battery pack caught fire in a } \\
\text { Boeing } 787 \text { traveling from } \\
\text { Yamaguchi-Ube to Tokyo. }\end{array}$ & Internal short circuit. \\
\hline 19 & January 2013 & Boston, USA & $\begin{array}{l}\text { The battery pack caught fire and } \\
\text { spread the smoke in the entire } \\
\text { cabin of a Boeing } 787 .\end{array}$ & Internal short circuit. \\
\hline 20 & May 2012 & Shenzhen, China & $\begin{array}{c}\text { An EV (BYD E6 taxi) car caught } \\
\text { fire after a rear-end collision and } \\
\text { hitting a tree. }\end{array}$ & $\begin{array}{l}\text { High-speed accident damaged the } \\
\text { high voltage circuit. Shorts } \\
\text { occurred in the broken circuit. }\end{array}$ \\
\hline 21 & July 2011 & Shanghai, China & An EV bus caught fire & Overheated $\mathrm{LiFePO}_{4}$ batteries \\
\hline 22 & May 2011 & Burlington, USA & $\begin{array}{l}\text { An EV (Chevy Volt) car caught } \\
\text { fire three weeks after a side-pole } \\
\text { impact test and damaged the } \\
\text { neighbouring cars. }\end{array}$ & $\begin{array}{l}\text { The pole impact broke the cooling } \\
\text { system and the battery module. } \\
\text { Coolant conducted an external } \\
\text { short circuit and ignited } \\
\text { combustible venting gas. }\end{array}$ \\
\hline 23 & April 2011 & Hangzhou, China & An EV (taxi) car caught fire. & Faulty battery. \\
\hline 24 & September 2010 & Dubai, UAE & $\begin{array}{l}\text { A Boeing B747-400F cargo plane } \\
\text { caught fire }\end{array}$ & Overheated batteries. \\
\hline 25 & January 2010 & Urumqi, China & Two EVs (buses) caught fire. & Overheated LiFePO4 batteries. \\
\hline 26 & July 2009 & Shenzhen, China & $\begin{array}{l}\text { Cargo plane caught fire before } \\
\text { flying to the USA. }\end{array}$ & Spontaneous combustion of LiBs. \\
\hline 27 & June 2008 & Tokyo, Japan & A HEV (Honda) caught fire. & Overheated LiFePO4 batteries. \\
\hline 28 & June 2008 & Columbia, USA & $\begin{array}{l}\text { The battery pack of an adjusted } \\
\text { HEV (Prius) car caught fire during } \\
\text { driving. }\end{array}$ & $\begin{array}{l}\text { Loose connection causing battery } \\
\text { to overheat. }\end{array}$ \\
\hline 29 & 2006-now & Worldwide & $\begin{array}{l}\text { Thousands of mobile phone fires } \\
\text { and/or explosions }\end{array}$ & $\begin{array}{l}\text { Internal shorts, manufacturer's } \\
\text { defect, overheating, etc. }\end{array}$ \\
\hline
\end{tabular}




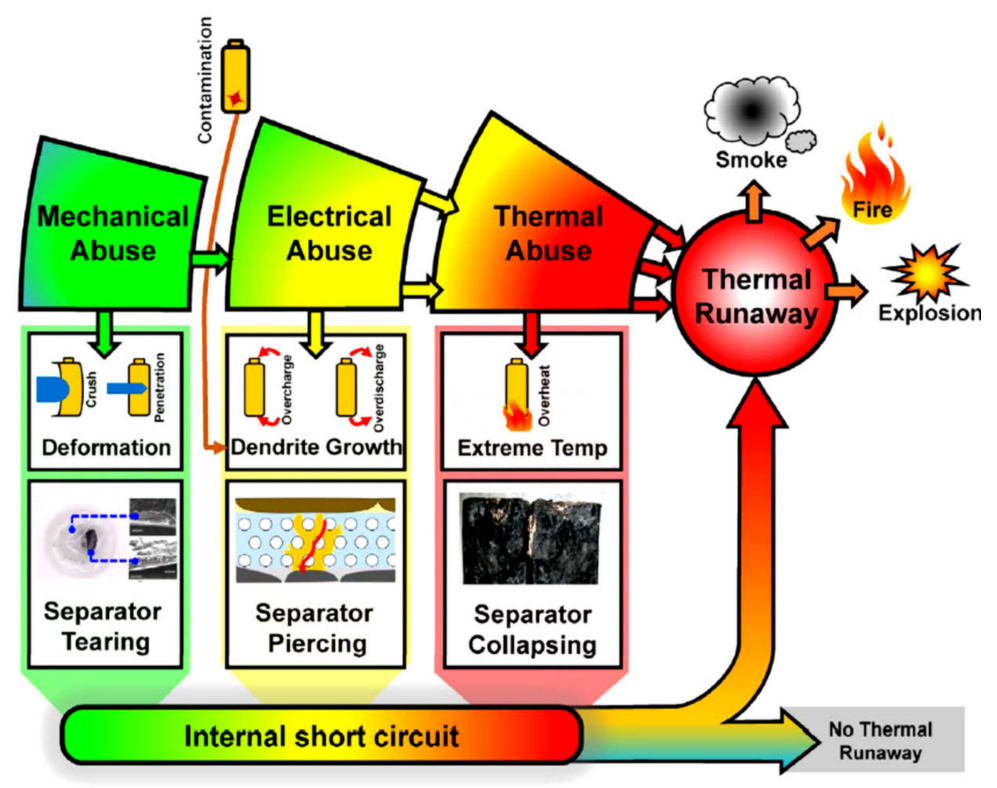

Figure 7. Various abuse conditions resulting in separator malfunction, subsequently internal short circuit, and possibly thermal runaway and fire [94].

\section{Fire Protection Techniques}

Fire protection measures are considered at the cell, battery, module, pack, system and enclosure levels. The fire protection plan must take into account hazards from outside the battery system and compartment producing more complications to the design of systems. Figure 8 depicts various levels of fire protection from cell components to system and compartment designs.

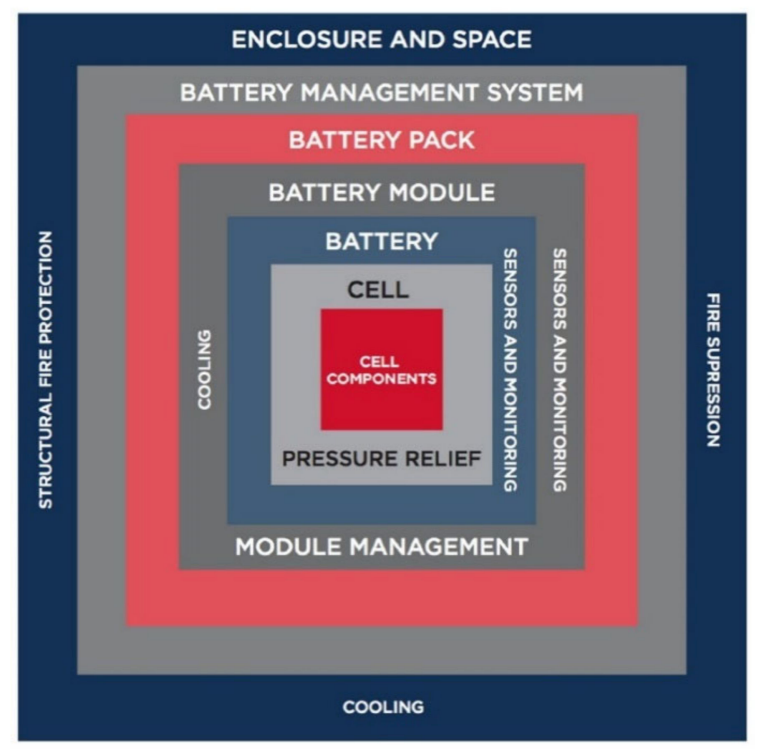

Figure 8. Levels of fire protection. Adapted from [116].

\subsection{Safety at Cell Level}

Within the cell, safety measures to reduce or prevent thermal runaway can be added through the modification of materials or structure, design, and utilisation of safety devices [117]. Significant works have been done to improve the safety of LiBs by modifying cathode and anode materials, and electrolyte chemistry. 
The choice of cathode material primarily determines the thermal stability and energy delivery. As an example, SEI decomposition begins around $130{ }^{\circ} \mathrm{C}$ for LCO, at $240{ }^{\circ} \mathrm{C}$ for NMC, at $270{ }^{\circ} \mathrm{C}$ for LMO and at $310^{\circ} \mathrm{C}$ for LFP cathodes [118]. The cathode material can be modified to improve thermal stability by coating with materials $[19,27]$ such as $\mathrm{TiO}_{2}[119], \mathrm{LiNi}_{0.5} \mathrm{Co}_{0.5} \mathrm{O}_{2}[120], \mathrm{Al}_{2} \mathrm{O}_{3}$, $\mathrm{MgO}$ [120], $\mathrm{Li}_{x} \mathrm{CoO}_{2}$ [120]; substitution of certain metals (e.g., nickel and aluminium partially replacing cobalt [121,122]); and doping with materials such as zirconium [123-127].

The anode surface can be modified for capacity retention at an elevated temperature of $50^{\circ} \mathrm{C}$ by deposition of $\mathrm{Al}_{2} \mathrm{O}_{3}$ [128], $\mathrm{SrO}, \mathrm{Mn}_{4} \mathrm{~N}, \mathrm{~K}_{2} \mathrm{SO}_{4}, \mathrm{CaCl}_{2}, \mathrm{CaF}_{2}, \mathrm{SrF}_{2}, \mathrm{Ag}, \mathrm{Mg}$ or $\mathrm{Zn}$ onto graphite [129]. The anode modification can be extended by smoothing the SEI surface and covering active edge structures by adding substances to the electrolyte such as phosphamide additives (N,N-diallyic-diethyoxyl phosphamide) [130-132], and substitution of conventional graphite anode with silicon [133], silicon nanowires [134] and spinel lithium titanate oxide, $\mathrm{Li}_{1.33} \mathrm{Ti}_{1.67} \mathrm{O}_{4}$ (LTO) [38]. It has been demonstrated through calorimetric analyses [135] and thermal runaway tests $[38,136]$ that LTO is a safer anode material compared to graphite.

The carbonated solvents of electrolyte are the main contributor to fire induced by LiB thermal runaway [67]. Reducing solvent and increasing lithium salt (e.g., $\mathrm{LiPF}_{6}$ ) content can decrease the electrolyte outgassing at temperatures above $100{ }^{\circ} \mathrm{C}$ [137], but changing the balance of lithium salt to solvent affects the thermal stability of the cathode and intercalated graphite [138-140]. The safety of electrolyte has been enhanced using additives [67-74, 121], for example: phosphonate electrolyte [67], tris(2,2,2-trifluoroethyl) phosphate [68,109], phosphates, phosphites [141], fluorinated propylene carbonates [142], nanodiamonds and nanoparticles [72], boron nitride aerogels and boron nitride nanotubes [73], fluorinated cyclotriphosphazene [69], hexamethoxy cyclotriphosphazene [143,144], vinylene carbonate [145], polymerizable monomer, 1,1' -(methylenedi-4,1-phenylene) bismaleimide [146], trimethyl phosphite and trimethyl phosphate [144], phosphazene-based flame retardants [147]). Substitution of electrolyte with ionic liquids [75-77] (e.g., 1-ethyl-3-methylimidazolium bis(fluorosulfonyl)imide [50], and solid polymer electrolyte [85-87] is another method to improve the safety of the electrolyte. Further information on each approach can be found in [118].

At the cell level, internal devices such as pressure relief vents, current interrupts, Positive Temperature Coefficient (PTC) devices and shutdown separators can prevent or limit the impact of internal malfunction [148]. Pressure relief vents release at elevated internal cell pressures directing the hot gas evacuation away from the cell and avoiding cell rupture [149-151]. The opening of the pressure relief vent is also associated with positive circuit cut-off preventing current flow. PTC devices, consisting of a conductive polymer which is a closed circuit in normal conditions, activate at abnormal high currents and high temperatures by melting the polymer [152] and breaking the circuit $[148,153]$. Shutdown separators consist of layered films with different phase transition temperatures which can close the separator pores and halt lithium ion transport [56,57].

\subsection{Safety at Module and Pack Level}

The Battery Management System (BMS) is the primary safety device at the module and pack level [90]. The BMS controls and prevents over-charge, over-discharge, and operates the battery pack for best application performance and long lifespan, generally achieved by balancing the state of charge of each cell [154]. BMS has attracted a lot of research interest over the past years to estimate accurately state of charge to avoid over-charging [155-157], and develop models for health prognosis [158,159], fault diagnostic [160-163], and charge control [164]. Figure 9 illustrates the response of the different safety devices to various abusive conditions. 


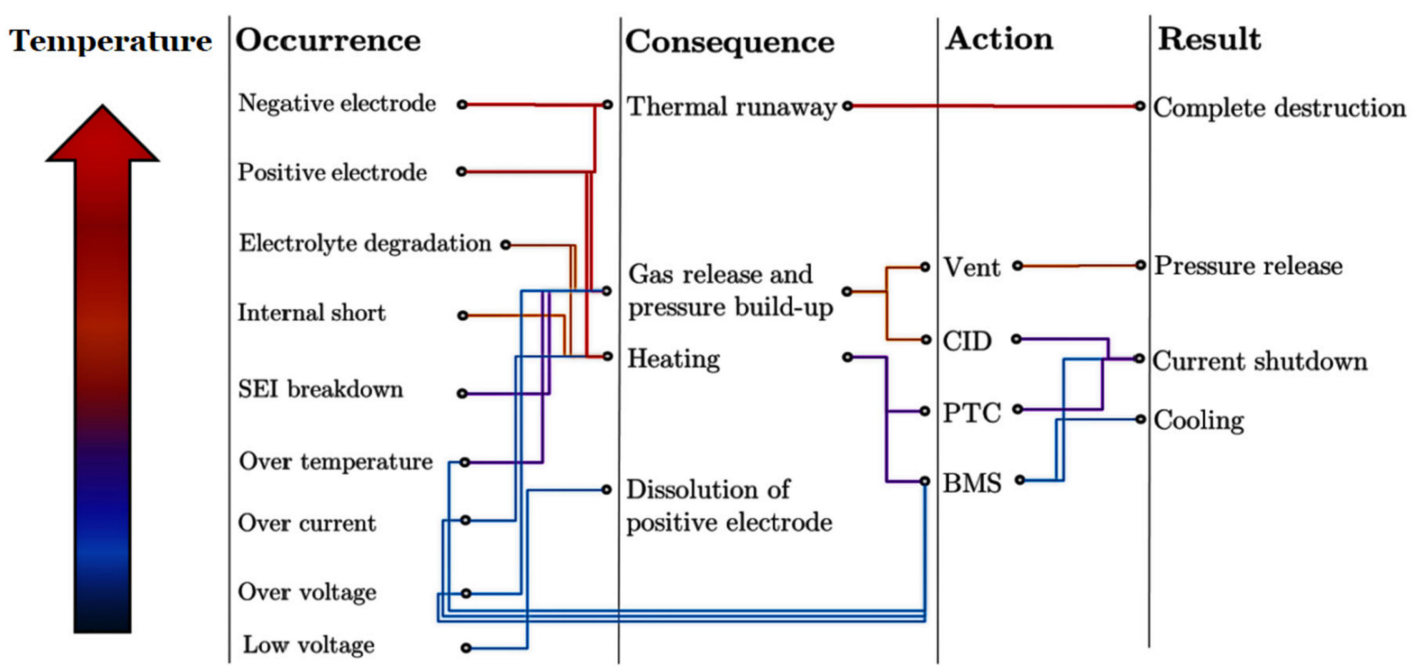

Figure 9. Results of various abuse conditions on a LiB with safety devices enabled [152]. BMS—battery management system, PTC—positive temperature coefficient device, CID—current interrupt device.

Together with the BMS, the Thermal Management System (TMS) provides safety protection to large battery packs. The TMS maintains an optimum operating temperature $\left(20^{\circ} \mathrm{C}\right.$ to $\left.40{ }^{\circ} \mathrm{C}[165,166]\right)$ for each cell and reduces temperature changes within and between modules. External heating devices are required to raise the temperature of battery packs if the temperature is below the desired range [167]. At temperatures above the desired set point, cooling technologies are needed to provide heat removal and prevent heat transfer between cells. The cooling techniques include one or a combination of spacing [168-170], air cooling (forced airflow) [171-173], liquid cooling [174,175], phase change material (PCM) cooling [116,165,176,177], or heat pipe cooling systems [178-180].

\subsection{Safety at Compartment Level}

Despite the safety measures at cell and module level, malfunctions in the safety system, accidental abuse or spontaneous internal short circuits may induce battery fire [118]. The fire safety measures developed at the cell level may not yet be available in cells selected for energy storage projects due to commercial (cost, schedule, availability) or cell performance reasons. Fire safety at the compartment level is then important to halt fire growth and prevent fire spread from the compartment. The battery compartment should be constructed to survive structurally and halt the spread of a fire to adjacent spaces. To prevent pressure build-up within the battery compartment during a thermal runaway event, incorporating an opening as a pressure relief exhaust is recommended, enabling systems within the compartment to withstand the pressure increases [116]. Lastly, an appropriate fire suppression system should be integrated into the design of the battery compartment.

\section{Lithium-Ion Battery Fire Detection and Suppression}

It has been shown that $\mathrm{LiB}$ fires can be detected using conventional heat detectors (reportedly the slowest method therefore not recommended), smoke detectors and combined smoke-heat detectors (reportedly the fastest method therefore recommended) [118].

Fire initiates when a fuel and an oxidiser are exposed to a source of heat, raising the temperature above the flash point of the fuel-oxidiser mixture. Interrupting any one of the four elements of fire-isolating the fuel from the ignition source, isolating the oxygen from the fuel, cooling the fuel below the ignition temperature, or interrupting the combustion reactions-can halt combustion. When the pressure build-up ruptures a lithium-ion cell, the flammable electrolyte is released, the thermal runaway process can supply adequate heat to initiate a fire.

There are six classes of fire and there are extinguishants to match the classes [115,181-183], each class is described below: 
- Class A-fires involving solid materials such as textiles, wood or paper.

- Class B-fires involving flammable liquids such as oils, petrol, or diesel.

- Class C-fires involving combustible gases.

- Class D-fires involving metals.

- Class E-fires involving energised electrical devices.

- Class F-fires involving combustible cooking oils such as in deep-fat fryers.

The fire class of a $\mathrm{LiB}$ fire is contentious due to the various components which make up the battery; separator material, construction material and electrodes (Class A), flammable liquid electrolyte (Class B) and energised electrical apparatus (Class E) [184]. The fire suppression method should suppress any $\mathrm{LiB}$ fire and control any rise in battery temperature. If not sufficiently cooled, thermal runaway reactions may continue and the battery re-ignite; this is a major challenge for $\mathrm{LiB}$ fire suppression systems. Adjacent cells may also undergo thermal runaway if heat propagation from the initial cell is not controlled. It is more important to cool the cells in a large battery pack, to prevent heat propagation, than to extinguish fires from a single cell. LiB firefighting strategies should be based on not only extinguishing the burning cell, but include cooling the burning cell as well as its adjacent cells.

The best practice fire extinguishing medium for LiBs is yet to be established $[5,116]$. Wilkens et al. [116] have listed, from a selection of LiB manufacturers, the recommended fire-extinguishing media for their batteries, obtained from their Material Safety Data Sheet (MSDS). This list is reproduced as Table 3.

Table 3. List of fire extinguishing media suggested by various lithium-ion battery manufacturers for their products as suggested in randomly selected MSDS [116].

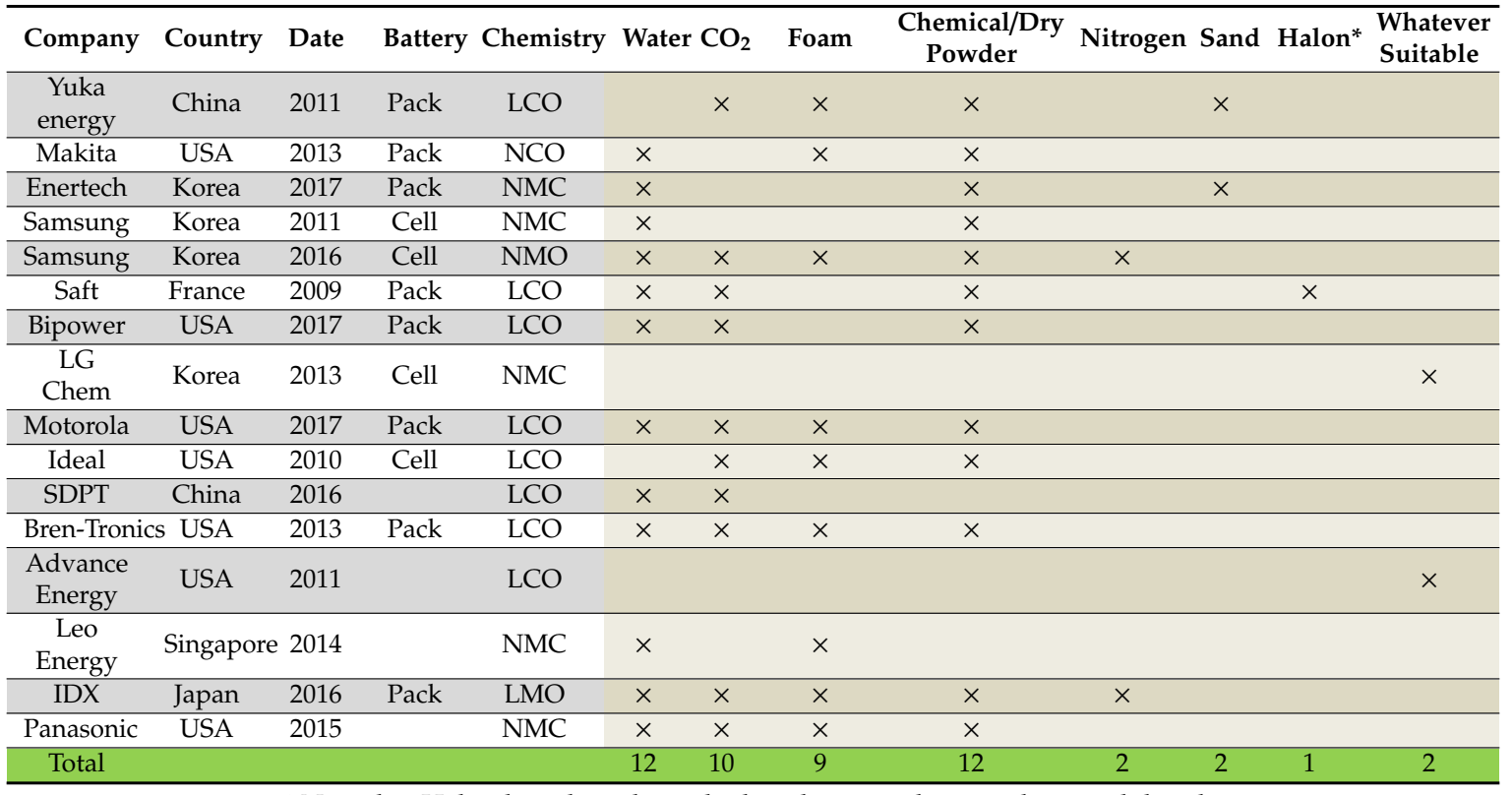

${ }^{*}$ Note that Halon-based products deplete the ozone layer and are prohibited.

It can be seen in Table 3 that the extinguishants most commonly recommended by manufacturers are water and chemical/dry powder, closely followed by CO2 and foam [185]. Details of commonly used extinguishants are provided in the next section. Some extinguishants may extinguish LiB electrolyte fires but may not control thermal runaway and the involvement of adjacent cells. 


\subsection{Types of Extinguishants—The Basics}

\subsubsection{Water Extinguishants}

Water-based extinguishants provide the most cost-effective method to fight fires $[185,186]$. Water is an excellent cooling medium due to its high heat capacity and latent heat of vaporisation and may be able to mitigate or halt the propagation of thermal runaway to surrounding batteries. It should be noted that water can react with $\mathrm{LiPF}_{6}$ and form toxic and harmful hydrogen fluoride (HF) [187], which may be chemically reduced by lithium and produce combustible hydrogen [188], conduct current and cause external short circuits in a cell which may result in LiB thermal runaway [118].

There are four types of water-based suppressants:

- Water jet: Water jet suppressants apply a stream of water directly to burning materials, providing cooling and inhibiting re-ignition. Water jets should not be employed on live electrical equipment due to electric shock concerns.

- Water spray or sprinkler: Water spray or sprinkler suppressants use a spray of fine water droplets, each droplet is surrounded by air, which is non-conductive. The spray has enough momentum for droplets to penetrate the fire plume and cool surfaces, as well as expanding some energy through vaporisation to cool the air.

- Water with added surfactants: Adding surfactants to the water can improve the efficacy of water extinguishment. Surfactants decrease the water's surface tension so that it coats the burning materials and cools more efficiently.

- Water mist: Water mist comprises a range of droplet sizes under $1000 \mu \mathrm{m}$, droplets that are much smaller than those from a sprinkler. Finer droplets have a larger surface area to volume ratio compared to larger droplets resulting in a greater absorption of heat energy from the hot air for the same volume of water, while the larger drops within the drop size distribution can penetrate the fire plume and cool the burning material.

\subsubsection{Foam Extinguishants}

Foam fire extinguishants can be used on Class A and Class B fires, therefore they can be employed to extinguish LiB fires [185]. The foam cools and seals the surface of a liquid or solid, putting a barrier between flammable vapour and the hot surface/fuel and starving the fire of air. To be effective the foam must fully encapsulate the cell which is a challenging task as LiBs are considered to have multi-stage jet fires, presenting high-velocity flammable gas venting.

\subsubsection{Powder/Dry Powder Extinguishants}

Powder extinguishants work by chemically interrupting the fire reactions. However, they do not provide cooling and re-ignition may occur. Powders may create breathing problems, especially inside enclosures [189].

\subsubsection{Carbon Dioxide $\left(\mathrm{CO}_{2}\right)$}

Carbon dioxide extinguishes by smothering the fire, replacing the oxygen in the combustion zone with $\mathrm{CO}_{2}$. $\mathrm{CO}_{2}$ can be used on Class $\mathrm{A}$ and $\mathrm{B}$ fires and is safe to use on electrical fires (Class $\mathrm{E}$ ). $\mathrm{CO}_{2}$ extinguishants do not leave any residue; however, their use can result in breathing issues, especially if used in enclosures. $\mathrm{CO}_{2}$ is not an ideal extinguishing agent for $\mathrm{LiB}$ fires due its low cooling capacity [188].

\subsubsection{Halon-Based Extinguishants}

Halon suppresses fire by chemically disrupting the combustion reactions. Halon 1211 (a liquid streaming extinguishant) and Halon 1301 (a gaseous flooding extinguishant) do not leave any residue and are rated for Class B and E fires, but are effective on Class A fires. Halons are global warming 
agents and deplete the ozone layer resulting in a cessation in production in 1994 under the Clean Air Act $[190,191]$, yet they remain an integral part of fire safety in many naval ships, aircraft, tanks, and submarines [192]. Halon-based extinguishants do not provide cooling.

\subsection{Lithium-Ion Battery Fire Suppression Studies}

Numerous researchers have studied LiB fires in order to find an effective suppressant. It has been reported by the National Technical Information Service $[193,194]$ that Halon-based products can extinguish a LiB fire [195], but cannot mitigate the internal temperature increase and stop re-ignition after the extinguishment of a fire [193]. In studies performed by Rao et al. [196], heptafluoropropane (HFC-227ea or FM200), a halogenated extinguishant which does not result in ozone depletion, showed superior behaviour in suppressing $\mathrm{LiB}$ fires when compared to carbon dioxide and powder extinguishants. The effectiveness of heptafluoropropane in suppressing LiB fires was also reported by Wang et al. [197], while Liu et al. [198] found Novec 1230 to be effective.

$\mathrm{LiB}$ fire suppression can also be achieved by applying large amounts of water to a battery or by submerging the battery in water [199]. Both of these methods can extinguish a LiB fire and cool the battery, inhibiting exothermic reactions and preventing re-ignition. This technique is impractical for large battery modules, although water sprinklers may be viable. Det Norske Veritas - Germanischer Lloyd (DNV-GL) [199] investigated the effectiveness of extinguishants such as F500 and FireIce (water surfactants), PyroCool (foam), Stat-X (aerosol) and water sprinklers in suppressing a LiB fire and cooling a battery undergoing thermal runaway. All systems extinguished the fires, but the water-based systems had better continued cooling ability. Egelhaaf et al. [200] demonstrated that water can suppress a LiB fire, and the addition of surfactant and gelling agents can decrease the volume of water required for firefighting. Tests performed by the Federal Aviation Administration (FAA) [201] concluded that water-based extinguishants (water, Hartindo AF-31, Aqueous A-B-D (Class A, B and D) are effective suppressant and coolant mediums compared to the non-aqueous extinguishants [199].

An alternative water extinguishing system is water mist [187,202-205]. Water mist may be an appropriate suppressant for large battery modules due to its low volumetric requirement and cooling capability. Testing conducted by the National Fire Protection Research Foundation, US, showed that water mist can effectively suppress a fire involving an electric vehicle battery [206]. It has also been demonstrated that the extinguishing effect of water mist can be improved by adding 5\% F500 solution and $5 \%$ anionic non-ionic surfactant to pure water [207]. The effectiveness of adding $3 \%$ aqueous film forming foam to water mist on re-ignition of a 18650-type $\mathrm{LiCoO}_{2}$ lithium ion battery pack $(10 \mathrm{Ah} \times 4)$ fire has been analysed by Li et al. [208]. It was reported that water mist with $3 \%$ aqueous film-forming foam was more effective in delaying the re-ignition compared to $\mathrm{ABC}$ dry powder extinguishers, and carbon dioxide.

Considering the potential effectiveness of water mist in suppressing LiB fires and cooling the battery to control thermal runaway, further details about the parametric water mist fire suppression systems (WMFSS) are presented next.

\subsection{Water Mist Characterisation}

To fully comprehend water mist spray dynamic, performance, and behaviour, the following parameters should be characterised [209]:

- $\quad$ Droplet size distribution (DSD);

- Spray cone angle;

- Spray velocity;

- Mass flow rate;

- Spray momentum.

The water mist characteristics will also be influenced by the existence of a fire but are first described in a non-fire environment. 


\subsubsection{Droplet Size Distribution (DSD)}

Water mist contains droplets of different sizes, which alters with time and location as the spray droplets collide, vaporise, or impinge on surfaces and drop out. The Droplet Size Distribution (DSD) refers to the range of droplet sizes presented in a mist spray. It influences the vaporisation rate, the spray dynamics, the entrainment of gases, and spray momentum relative to the buoyancy of the fire plume. Generally, the size of drops in a spray is defined by a single droplet size parameter, such as a mass mean diameter (MMD) or volumetric median diameter (VMD) [210]. The VMD, expressed as $\operatorname{VMD}\left(D_{\mathrm{V}} 0.5\right)$, denotes the midpoint droplet size, where $50 \%$ of the volume of spray contains smaller particles, and the other $50 \%$ of the volume, larger particles than the mean. The most common measure of droplet size is the sauter mean diameter (SMD) which is the mean diameter with the same ratio of volume to surface area as the entire domain. It should be mentioned that a single parameter cannot fully determine a drop size distribution as two sprays with the same VMD or SMD are not necessarily alike. To demonstrate, NFPA 750 [211] employed the curve of cumulative volume percentage versus diameter to indicate the distribution of mass, volume and drop sizes in a water mist.

It has been reported [212,213] that water mists with SMDs smaller than $300 \mu \mathrm{m}$ can significantly cool and extinguish diffusion flames. The efficacy of the WMFSS depends on the range of particle sizes produced. Smaller droplets create larger surface areas and improve vaporisation rate and cooling effect, which increases the efficiency of the WMFSS by decreasing the amount of water required for fire suppression [210]. In contrast, droplets of a larger size have higher momentum enabling them to have a greater capability of entering a fire plume and smoke layer, and consequently wet and cool burning materials and hot gases. Thus, a spray with larger droplets may be more effective to finer droplets in extinguishing an unobstructed fire, whereas a spray with finer droplets may be more effective over the larger droplets in extinguishing an obstructed fire [210].

\subsubsection{Spray Cone Angle}

Solid cone nozzles are usually utilised in WMFSSs, producing either $90^{\circ}$ or $120^{\circ}$ spray cones (surrounding the central, straight-through axis) [210]. Other cone angles are possible but not commercially available for fire extinguishment systems.

A solid cone nozzle forms a full-cone spray that is more diluted downstream of the nozzle by the entrainment of gases. Most of the water mass is located near the spray central axis, while the outer spray regions contain less liquid mass and more water vapour. Droplet velocities are also much higher in the region closer to the spray axis and decrease in the radial direction due to interaction with entrained gases. Smaller spray cone angles lead to a denser spray with a higher probability of droplet collisions. These collisions can result in a change of droplet velocity and size which can affect the vaporisation and cooling rates. Droplets can either disintegrate into smaller drops or combine to form larger drops (droplet coalescence) [214].

\subsubsection{Spray Velocity}

The magnitude of spray velocity determines the atomisation regime, while the direction of the penetrating jet defines the shape of the spray cone. The velocity of each individual droplet is transferred to the surrounding air through the drag effects which enhances the air entrainment and increases the mass flux of the spray cone. Spray mass flux and velocity (velocity of water droplets plus the air entrained in the flow) determines the spray momentum dictating the total effect of the spray on a fire plume [210].

\subsubsection{Mass Flow Rate}

The mass flow (discharge) rate of the spray is dependent on the injection pressure and the total area of the nozzle orifice. To design a nozzle, its required mass flow rate can be estimated using 
the spray heat absorption ratio (SHAR) or required extinguishing medium portion (REMP) values, discussed by Mawhinney et al. [210].

\subsubsection{Spray Momentum}

Spray momentum is calculated as the summation of mass of water droplets and the mass of entrained air, multiplied by the velocity of the droplets and entrained air. For a constant mass discharge rate, an increase in spray velocity also increases the air entrainment rate, which subsequently increases the spray momentum. The direction of the spray momentum plays a significant role in fire suppression as an injection above the fire plume may lead to the water mist penetration and vaporisation where the water vapour can reach the seat of the fire [210]. An injection under the fire plume with co-directional flows may not generate the turbulent flame mist mixing required to improve vaporisation and cooling, and the water vapour produced will be moved away from the burning surface instead of driven down to it. To assess the benefits of utilising high- or low-velocity water mist nozzles, the directional component of the momentum in addition to the magnitude of spray velocities should be taken into account.

\subsection{Water Mist Nozzle Characteristics}

Structure of spray is mainly determined by the type and operating conditions of the nozzle such as the injection pressure. Nozzles basically can be divided into two categories: single- and multiple-hole nozzles. Considering the spray pattern, nozzles can be categorised into full cone, hollow cone, or flat spray. In water mist systems, various types of nozzles are used including single and multiple orifice nozzles which can produce different pattern based on the application. Figure 10 shows different types of nozzles and their spray patterns.

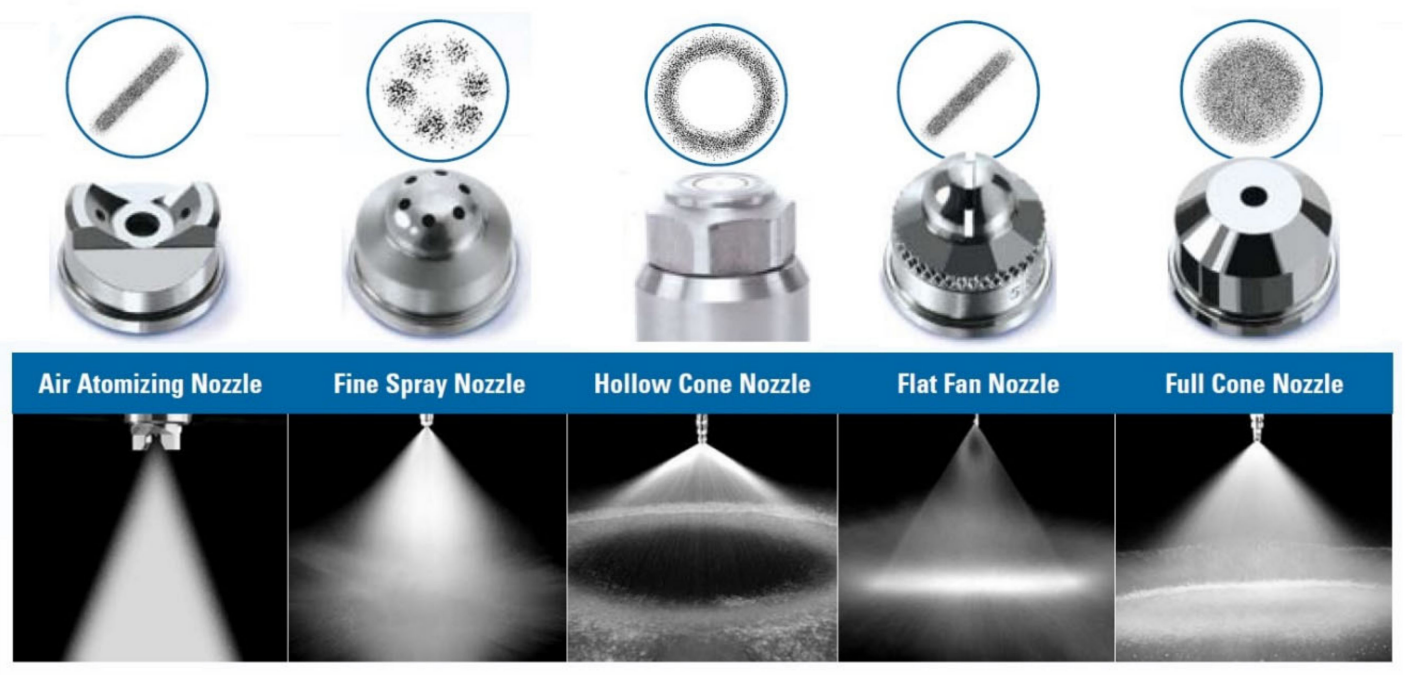

Figure 10. Nozzle types and their spray patterns.

\subsection{Mechanisms of Fire Extinguishment using Water Mist}

There are five mechanisms associated with a WMFSS in a closed compartment [215]:

- Gas-phase cooling;

- Oxygen depletion and flammable vapour dilution;

- Wetting and cooling of the fuel surface;

- Radiation attenuation;

- Kinetic effects, enclosure effects, turbulent mixing and cycling.

Generally, all mechanisms take place to some extent during fire suppression of LiB fires in enclosures. 


\subsubsection{Gas-Phase Cooling}

Water mist consists of very fine droplets: generating fine droplets increases the surface area to volume ratio of the droplets enhancing the rate of vaporisation by absorption of heat from the flames, hot combustion gases, smoke layer and hot surfaces [216].

In the gas-phase cooling process, the heat in the combustion zone is absorbed by the vaporisation of water droplets which leads to a decrease in the temperature of the flames. The flames will be extinguished if the temperature falls below the critical temperature required to maintain combustion. The cooling process also diminishes the flame radiation to the fuel surface, decreasing the fuel pyrolysis rate.

\subsubsection{Oxygen Depletion and Flammable Vapour Dilution}

With a WMFSS, the water droplets are vapourised and the total volume occupied by the water vapour increases by more than three orders of magnitude [210]. The water volume expansion results in disruption of air entrainment into the flame and dilution of both oxygen and flammable vapour concentration around the flame. The decrease in the oxygen concentration in an enclosure due to the introduction of water mist is dependent on the fire size and the length of the pre-suppression period, the enclosure volume and ventilation conditions in the enclosure [216].

A fire can be extinguished if the oxygen concentration falls below that necessary to maintain combustion, the limiting oxygen concentration [50]. The concentration of oxygen can be reduced by a combination of (a) depletion due to consumption by fire, (b) dilution due to displacement by the water vapour, and (c) dilution by combustion products [217]. The oxygen depletion, displacement, and flammable vapour dilution in a fire environment are depicted in Figure 11.

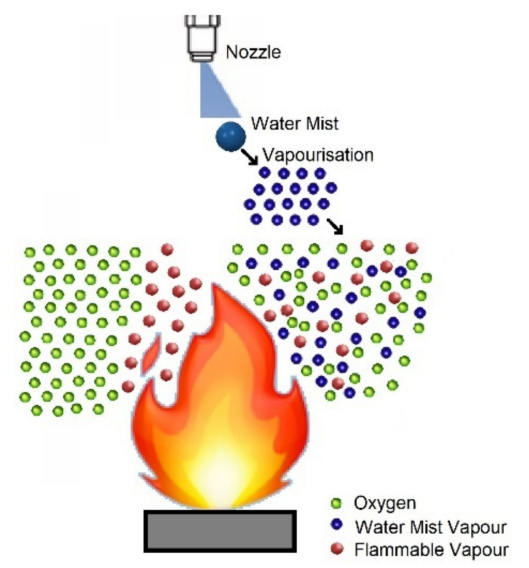

Figure 11. Schematic of oxygen displacement, depletion and flammable vapour dilution induced by the water mist vaporisation in the fire environment.

\subsubsection{Wetting and Cooling of the Fuel Surface}

The main extinguishment mechanism for many solid and liquid fuels is wetting and cooling of the fuel surface. Much like a sprinkler, the larger drop sizes have sufficient momentum to penetrate the fire plume to reach the seat of the fire. This process is associated with a reduction in the pyrolysis rate of the fuel.

\subsubsection{Radiation Attenuation}

Radiation attenuation occurs due to the presence of water vapour between the fuel and the flame. The water vapour absorbs radiant energy, re-radiating at a lower intensity to the fuel surface [50].

Water droplets convecting within a compartment also absorb heat and reduce radiation to and from walls, as reported in a study by Mawhinney et al. [215] where the radiant heat flux to the walls in 
an enclosure could be decreased by $70 \%$ using a WMFSS. It has been found that finer droplets can attenuate the thermal radiation at a lower concentration of water when compared to larger spray droplets [218]. The mechanism of radiation attenuation generated by a water-mist spray is shown in Figure 12.

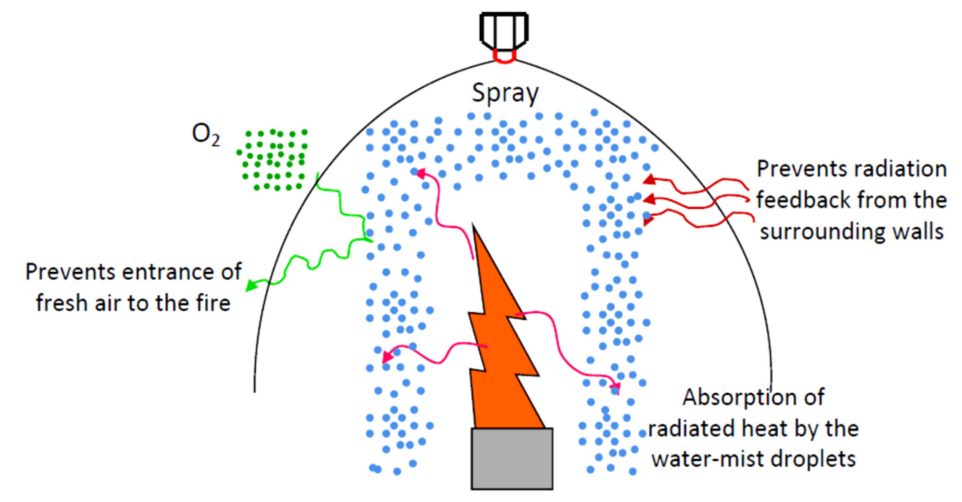

Figure 12. Schematic of attenuation of thermal radiation by a water-mist spray [216].

\subsubsection{Kinetic Effects, Enclosure Effects, Turbulent Mixing and Cycling}

Kinetics refers to the effects that the environmental variables have on the chemical reaction rates and formation of intermediate reaction compounds.

Water mist can vary the kinetics which can intensify or extinguish the flame [215]. The flame may be intensified on first contact with the water mist due to vaporisation at the flame surface increasing turbulence and entrainment [210]. This can increase the fuel/air mixing, causing an increase in combustion rate and a flare-up of the fire [210]. Alternatively, kinetic effects may lead to fire suppression due to gas-phase cooling and oxygen depletion/dilution. The water mist and entrained and vitiated gases dilute the combustible gases and when combined with flame cooling, varies the combustion rate from its stoichiometric condition that may extinguish the flame.

Enclosure effects have been investigated by Mawhinney et al. [215] and Liu et al. [219]. In enclosures, the influences of oxygen depletion and dilution are intensified. When water mist is initiated, the hot gases trapped in the upper layer of a closed compartment are cooled quickly. The momentum of the expanding water vapour carries the mixture of water vapour and gases toward the fire, leading to localised oxygen depletion. Depending on the temperature and depth of the hot layer, the cooling of the hot gases can lead to a volume contraction, producing a negative pressure [210]. If flashover occurs before mist activation, it is difficult to determine whether the expansion due to mist vaporisation or contraction due to cooling will dominate. To halt the creation of a negative pressure pulse, water mist can be injected in multiple steps. This process has been used by Liu et al. [219] to demonstrate an improvement in suppressing fires in enclosures.

\subsection{Water Mist Fire Suppression System Characteristics}

The performance of the WMFSS is primarily determined by the characteristics of sprays generated by nozzles [220]. Different types of nozzles, e.g., single- and multi-hole, can significantly vary the mass distribution of sprays. The single-hole nozzle produces relatively larger droplets, longer penetration length with a higher concentration in the region beneath the nozzle in comparison with the multi-hole nozzle [216].

Typically, WMFSS consist of multiple nozzles where the spacing between nozzles and distance from the floor/target (here the LiB) are determined by the distribution of the flux density of individual nozzles and the size of compartment and potential fire. The position of the nozzle can affect the performance of the suppression system. If a nozzle is located directly above a fire, the water droplets of the spray will travel the least distance to reach the fire and may show better performance in suppressing 
the fire. In contrast, while installation of multiple nozzles will involve a higher cost for the system, multiple nozzles may show better performance in suppressing the fire by distributing mists more uniformly and enhancing the oxygen depletion process. However, activation of two nozzles may render a drop in the pressure of the water supply and reduce the performance of the spray [216].

The design of WMFSS is considered as "project specific", where each particular hazard or occupancy requires its own specific design for the optimum efficiency. It is therefore not possible to design a mist system simply by reference to one of the standards available such as NFPA 750 [211], BS 8489 [221], or CEN TS 14972 [222]. For example, while BS 8489 sets out the design criteria for a water mist system, its suitability for a particular fire risk should be examined according acceptable test protocols. For a lithium-ion battery compartment, a suitable WMFSS (with or without complementary suppressing agents such as surfactants, foam or gas) might include a zonal approach, based on each module, where the fire suppression system automatically activates on detection of a local temperature increase (beyond the thermal and battery management systems), thus enabling early intervention, and possibly avoiding heat transfer to adjoining cells, major battery damage and other fire damage.

\section{Summary and Outlook}

LiBs attract interest due to their high voltage capability, superior energy density, lightweight, low self-discharge and long lifespan for electrical energy storage. Any abuse condition (thermal, electrical, and mechanical) that is beyond the safe operating window can affect the performance of the battery and cause safety concerns such as thermal runaway, electrolyte gas venting, fire and explosion. The hazards and safety concerns associated with the use of LiBs are an important consideration in battery selection. Numerous LiB fires and explosion incidents have been reported; therefore, measures should be taken at different levels (design of batteries, chemistry, safety components and firefighting) to alleviate fire concerns. Techniques to improve the safety of LiBs at the cell, module, pack and compartment levels to mitigate the fire risk have been reviewed. Currently, limited lithium-ion cells are constructed with safe cell chemistry and internal components, and these safety features may not be available in cells selected for energy storage projects due to commercial (cost, schedule, availability) or performance reasons. Battery management systems that maintain a safe operating environment for modules and packs, are well established, with constant advances being applied. However, fire incidents do still occur.

Although fires involving LiBs can be extinguished by many methods, the effects of thermal runaway are more difficult to manage and continued cooling is required. The associated problems also often become exacerbated as $\mathrm{LiB}$ assemblies tend to be in a tightly packed configuration, and are kept in enclosures with minimum leeway and free spaces. Therefore, battery compartment construction and design should maintain an intact boundary to a fire or explosion, but should also include passive thermal management utilising a combination of space separation, cooling, and zonal fire suppression within a module, and insulation between battery modules to limit thermal runaway to adjacent modules. Given that many of the halon-based firefighting agents are banned owing to their environmental implications and that inert gases, such as nitrogen or argon, are less effective in their own right, the main impetus in finding alternative ways of fighting $\mathrm{LiB}$ fires mainly hinges on enhancing the effectiveness of, and perhaps finding smarter ways of deploying, water as the most efficient medium for continuous extinguishing and cooling. In this context, the extinguishment may be enhanced by using environmentally friendly additives, or, better yet, in combination with an inert gas stream such as nitrogen, and the cooling improved through better design and implementation of spray systems. In both counts, water is the ideal medium for obvious reasons. Water mist is now well established as a fire suppression technique, but limited information is available for suppressing LiB fires. Water mist with additives and surfactants, or in conjunction with a gaseous extinguishing medium, is considered the most promising extinguishing and cooling method for LiBs. Further investigations on the thermal behaviour of LiBs during firefighting using water mist and different mediums are necessary to establish appropriate guidelines to extinguish LiB fires. 
Author Contributions: Conceptualization, Writing-original draft, Visualization, M.G.; Project administration, Resources, Supervision, V.N.; Conceptualization, Funding acquisition, Resources, Supervision, K.M.; Writing-Review \& Editing, Resources, Supervision, P.J.; Writing-review \& editing, Resources, Data Curation, I.B.; Writing-review \& editing, Conceptualization, Data Curation, B.S.; Writing-Review \& Editing, Resources, Funding acquisition, Project administration, G.G. All authors have read and agreed to the published version of the manuscript.

Funding: This work was supported by Victoria University and the Defence Science and Technology of Australia.

Acknowledgments: One of us, M.G., is grateful to Victoria University and the Defence Science and Technology of Australia for the provision of a post-doctoral research fellowship.

Conflicts of Interest: The authors declare no conflict of interest

\section{Nomenclature:}

\begin{tabular}{|c|c|}
\hline BMS & Battery Monitoring System \\
\hline CID & Current Interrupt Device \\
\hline DEC & Diethyl Carbonate \\
\hline DMC & Dimethyl Carbonate \\
\hline DNV-GL & Det Norske Veritas and Germanischer Lloyd \\
\hline DSD & Droplet Size Distribution \\
\hline EC & Ethylene Carbonate \\
\hline EMC & Ethyl Methyl Carbonate \\
\hline EV & Electric Vehicle \\
\hline FAA & Federal Aviation Administration \\
\hline FDS & Fire Dynamics Simulator \\
\hline $\mathrm{HEV}$ & Hybrid Electric Vehicle \\
\hline $\mathrm{HF}$ & Hydrogen Fluoride \\
\hline HRR & Heat Release Rate \\
\hline ISC & Internal Short Circuit \\
\hline $\mathrm{LCO}$ & Lithium Cobalt Oxide \\
\hline LCP & Lithium Cobalt Phosphate \\
\hline LFP & Lithium Iron Phosphate \\
\hline LFSF & Lithium Iron Fluorosulphate \\
\hline $\mathrm{LiB}$ & Lithium-ion Battery \\
\hline $\mathrm{LMO}$ & Lithium Manganese Oxide \\
\hline LTO & Lithium Titanate Oxide \\
\hline LTS & Lithium Titanium Sulphide \\
\hline MMD & Mass Mean Diameter \\
\hline MSDS & Material Safety Data Sheet \\
\hline NCA & Nickel Cobalt Aluminium Oxide \\
\hline $\mathrm{NCM}$ & Nickel Cobalt Manganese Oxide \\
\hline NFPA & National Fire Protection Association \\
\hline PC & Propylene Carbonate \\
\hline PCM & Phase Change Material \\
\hline PE & Polyethylene \\
\hline PP & Polypropylene \\
\hline PTC & Positive Temperature Coefficient \\
\hline REMP & Required Extinguishing Medium Portion \\
\hline SEI & Solid-Electrolyte Interface \\
\hline SFPE & Society of Fire Protection Engineers \\
\hline SHAR & Spray Heat Absorption Ratio \\
\hline SMD & Sauter Mean Diameter \\
\hline TMS & Thermal Management System \\
\hline VMD & Volumetric Median Diameter \\
\hline WMFSS & Water Mist Fire Suppression System \\
\hline
\end{tabular}




\section{References}

1. Whittingham, M.S. Chalcogenide Battery. U.S. Patent No. 4,009,052, 22 February 1977.

2. Mizushima, K.; Jones, P.C.; Wiseman, P.J.; Goodenough, J.B. $\mathrm{Li}_{\mathrm{x}} \mathrm{CoO}_{2}(0<\mathrm{x}<-1)$ : A new cathode material for batteries of high energy density. Mater. Res. Bull. 1980, 15, 783-789.

3. Thackeray, M.; David, W.; Bruce, P.; Goodenough, J.B. Lithium insertion into manganese spinels. Mater. Res. Bull. 1983, 18, 461-472. [CrossRef]

4. Yamahira, T.; Kato, H.; Anzai, M. Nonaqueous Electrolyte Secondary Battery. U.S. Patent No. 5,053,297, 1 October 1991.

5. Blum, A.F.; Long, R.T., Jr. Fire Hazard Assessment of Lithium Ion Battery Energy Storage Systems; Springer: New York, NY, USA, 2016.

6. Whittingham, M.S. Electrical energy storage and intercalation chemistry. Science 1976, 192, $1126-1127$. [CrossRef] [PubMed]

7. Tarascon, J.-M.; Armand, M. Issues and challenges facing rechargeable lithium batteries. Nature 2001, 414, 359-367. [CrossRef] [PubMed]

8. Pacala, S.; Socolow, R. Stabilization wedges: Solving the climate problem for the next 50 years with current technologies. Science 2004, 305, 968-972. [CrossRef]

9. Cavanagh, K.; Ward, J.; Behrens, S.; Bhatt, A.; Ratnam, E.; Oliver, E.; Hayward, J. Electrical Energy Storage: Technology Overview and Applications; CSIRO: Canberra, Australia, 2015.

10. Roy, P.; Srivastava, S.K. Nanostructured anode materials for lithium ion batteries. J. Mater. Chem. A 2015, 3, 2454-2484. [CrossRef]

11. Nitta, N.; Wu, F.; Lee, J.T.; Yushin, G. Li-ion battery materials: Present and future. Mater. Today 2015, 18, 252-264. [CrossRef]

12. Li, J.; Suzuki, T.; Naga, K.; Ohzawa, Y.; Nakajima, T. Electrochemical performance of $\mathrm{LiFePO}_{4}$ modified by pressure-pulsed chemical vapor infiltration in lithium-ion batteries. Mater. Sci. Eng. B 2007, 142, 86-92. [CrossRef]

13. Takahashi, M.; Ohtsuka, H.; Akuto, K.; Sakurai, Y. Confirmation of long-term cyclability and high thermal stability of LiFePO4 in prismatic lithium-ion cells. J. Electrochem. Soc. 2005, 152, A899-A904. [CrossRef]

14. Zaghib, K.; Shim, J.; Guerfi, A.; Charest, P.; Striebel, K.A. Effect of carbon source as additives in LiFePO4 as positive electrode for lithium-ion batteries. Electrochem. Solid-State Lett. 2005, 8, A207-A210. [CrossRef]

15. Jiang, J.; Dahn, J.R. ARC studies of the thermal stability of three different cathode materials: $\mathrm{LiCoO}_{2}$; $\mathrm{Li}\left[\mathrm{Ni}_{0.1} \mathrm{Co}_{0.8} \mathrm{Mn}_{0.1}\right] \mathrm{O}_{2}$; and $\mathrm{LiFePO}_{4}$, in $\mathrm{LiPF}_{6}$ and $\mathrm{LiBoB} \mathrm{EC} / \mathrm{DEC}$ electrolytes. Electrochem. Commun. 2004, 6, 39-43. [CrossRef]

16. Dong, Y.Z.; Zhao, Y.M.; Chen, Y.H.; He, Z.F.; Kuang, Q. Optimized carbon-coated LiFePO4 cathode material for lithium-ion batteries. Mater. Chem. Phys. 2009, 115, 245-250. [CrossRef]

17. Armand, M.; Tarascon, J.-M. Building better batteries. Nature 2008, 451, 652-657. [CrossRef] [PubMed]

18. Martha, S.K.; Haik, O.; Zinigrad, E.; Exnar, I.; Drezen, T.; Miners, J.H.; Aurbach, D. On the thermal stability of olivine cathode materials for lithium-ion batteries. J. Electrochem. Soc. 2011, 158, A1115-A1122. [CrossRef]

19. Shi, J.L.; Xiao, D.D.; Ge, M.; Yu, X.; Chu, Y.; Huang, X.; Zhang, X.D.; Yin, Y.X.; Yang, X.Q.; Guo, Y.G. High-Capacity Cathode Material with High Voltage for Li-Ion Batteries. Adv. Mater. 2018, 30, 1705575. [CrossRef] [PubMed]

20. Xia, Y.; Zheng, J.; Wang, C.; Gu, M. Designing principle for Ni-rich cathode materials with high energy density for practical applications. Nano Energy 2018, 49, 434-452. [CrossRef]

21. Sun, Y.-Y.; Liu, S.; Hou, Y.-K.; Li, G.-R.; Gao, X.-P. In-situ surface modification to stabilize Ni-rich layered oxide cathode with functional electrolyte. J. Power Sources 2019, 410, 115-123. [CrossRef]

22. Li, Y.; Li, X.; Wang, Z.; Guo, H.; Li, T.; Meng, K.; Wang, J. A novel layered Ni-rich cathode hierarchical architecture of densely integrating hydroxide nanoflakes onto oxide microspheres with superior lithium storage property. Mater. Chem. Front. 2018, 2, 1822-1828. [CrossRef]

23. Chen, R.; Zhang, H.; Xie, J.; Lin, Y.; Yu, J.; Chen, L. Preparation, Lithium Storage Performance and Thermal Stability of Nickel-Rich Layered $\mathrm{LiNi}_{0 .}{ }_{815} \mathrm{Co}_{0 .}{ }_{15} \mathrm{Al}_{0 .}{ }_{035} \mathrm{O}_{2} / \mathrm{RGO}$ Composites. ChemElectroChem 2018, 5, 3176-3182.

24. Jang, S.H.; Jung, K.; Yim, T. Silyl-group functionalized organic additive for high voltage Ni-rich cathode material. Curr. Appl. Phys. 2018, 18, 1345-1351. [CrossRef] 
25. Nayak, P.K.; Erickson, E.M.; Schipper, F.; Penki, T.R.; Munichandraiah, N.; Adelhelm, P.; Sclar, H.; Amalraj, F.; Markovsky, B.; Aurbach, D. Review on challenges and recent advances in the electrochemical performance of high capacity Li-and Mn-rich cathode materials for Li-ion batteries. Adv. Energy Mater. 2018, 8, 1702397. [CrossRef]

26. Hou, X.; Wang, Y.; Song, J.; Gu, H.; Guo, R.; Liu, W.; Mao, Y.; Xie, J. Electrochemical behavior of Mn-based Li-rich cathode material $\mathrm{Li}_{1.15} \mathrm{Ni}_{0 .}{ }_{17} \mathrm{Co}_{0 .}{ }_{11} \mathrm{Mn}_{0 .}{ }_{57} \mathrm{O}_{2}$ fluorinated by Nh4f. Solid State Ion. 2018, 325, 1-6.

27. Liu, Y.; Fan, X.; Zhang, Z.; Wu, H.-H.; Liu, D.; Dou, A.; Su, M.; Zhang, Q.; Chu, D. Enhanced electrochemical performance of Li-rich layered cathode materials by combined $\mathrm{Cr}$ doping and $\mathrm{LiAlO}_{2}$ coating. Acs Sustain. Chem. Eng. 2018, 7, 2225-2235. [CrossRef]

28. Zhou, H.; Yang, Z.; Yin, C.; Yang, S.; Li, J. Fabrication of nanoplate Li-rich cathode material via surfactant-assisted hydrothermal method for lithium-ion batteries. Ceram. Int. 2018, 44, 20514-20523. [CrossRef]

29. Ding, X.; Xiao, L.-N.; Li, Y.-X.; Tang, Z.-F.; Wan, J.-W.; Wen, Z.-Y.; Chen, C.-H. Improving the electrochemical performance of $\mathrm{Li}$-rich $\mathrm{Li}_{1.2} \mathrm{Ni}_{0.2} \mathrm{Mn}_{0 .}{ }_{6} \mathrm{O}_{2}$ by using Ni-Mn oxide surface modification. J. Power Sources 2018, 390, 13-19. [CrossRef]

30. Li, X.; Zhang, K.; Mitlin, D.; Paek, E.; Wang, M.; Jiang, F.; Huang, Y.; Yang, Z.; Gong, Y.; Gu, L. Li-Rich Li [Li1/6Fe1/6Ni1/6Mn1/2] O2 (LFNMO) Cathodes: Atomic Scale Insight on the Mechanisms of Cycling Decay and of the Improvement due to Cobalt Phosphate Surface Modification. Small 2018, 14, 1802570. [CrossRef]

31. Li, X.; Qiao, Y.; Guo, S.; Jiang, K.; Ishida, M.; Zhou, H. A New Type of Li-Rich Rock-Salt Oxide $\operatorname{Li}_{2} \mathrm{Ni}_{1 / 3} \mathrm{Ru}_{2 / 3} \mathrm{O}_{3}$ with Reversible Anionic Redox Chemistry. Adv. Mater. 2019, 31, 1807825. [CrossRef]

32. Wang, X.; Feng, Z.; Huang, J.; Deng, W.; Li, X.; Zhang, H.; Wen, Z. Graphene-decorated carbon-coated $\mathrm{LiFePO}_{4}$ nanospheres as $a$ high-performance cathode material for lithium-ion batteries. Carbon 2018, 127, 149-157. [CrossRef]

33. Yao, J.; Li, Y.; Massé, R.C.; Uchaker, E.; Cao, G. Revitalized interest in vanadium pentoxide as cathode material for lithium-ion batteries and beyond. Energy Storage Mater. 2018, 11, 205-259. [CrossRef]

34. Bak, S.-M.; Shadike, Z.; Lin, R.; Yu, X.; Yang, X.-Q. In situ/operando synchrotron-based X-ray techniques for lithium-ion battery research. NPG Asia Mater. 2018, 10, 563-580. [CrossRef]

35. Nam, K.W.; Bak, S.M.; Hu, E.; Yu, X.; Zhou, Y.; Wang, X.; Wu, L.; Zhu, Y.; Chung, K.Y.; Yang, X.Q. Combining in situ synchrotron $X$-ray diffraction and absorption techniques with transmission electron microscopy to study the origin of thermal instability in overcharged cathode materials for lithium-ion batteries. Adv. Funct. Mater. 2013, 23, 1047-1063. [CrossRef]

36. McDowall, J. Understanding lithium-ion technology. In Proceedings of the Battcon, Marco Island, FL, USA, 5-7 May 2008.

37. Huang, P.; Ping, P.; Li, K.; Chen, H.; Wang, Q.; Wen, J.; Sun, J. Experimental and modeling analysis of thermal runaway propagation over the large format energy storage battery module with Li4Ti5O12 anode. Appl. Energy 2016, 183, 659-673. [CrossRef]

38. Yao, X.; Xie, S.; Chen, C.; Wang, Q.; Sun, J.; Li, Y.; Lu, S. Comparisons of graphite and spinel Li1. 33Ti1. 67O4 as anode materials for rechargeable lithium-ion batteries. Electrochim. Acta 2005, 50, 4076-4081. [CrossRef]

39. Kim, H.; Han, B.; Choo, J.; Cho, J. Three-dimensional porous silicon particles for use in high-performance lithium secondary batteries. Angew. Chem. Int. Ed. 2008, 47, 10151-10154. [CrossRef] [PubMed]

40. Liu, J.; Kopold, P.; van Aken, P.A.; Maier, J.; Yu, Y. Energy storage materials from nature through nanotechnology: A sustainable route from reed plants to $a$ silicon anode for lithium-ion batteries. Angew. Chem. Int. Ed. 2015, 54, 9632-9636. [CrossRef]

41. Zhang, W.M.; Hu, J.S.; Guo, Y.G.; Zheng, S.F.; Zhong, L.S.; Song, W.G.; Wan, L.J. Tin-nanoparticles encapsulated in elastic hollow carbon spheres for high-performance anode material in lithium-Ion batteries. Adv. Mater. 2008, 20, 1160-1165. [CrossRef]

42. Prikhodchenko, P.V.; Gun, J.; Sladkevich, S.; Mikhaylov, A.A.; Lev, O.; Tay, Y.Y.; Batabyal, S.K.; Yu, D.Y. Conversion of hydroperoxoantimonate coated graphenes to Sb2S3@ graphene for a superior lithium battery anode. Chem. Mater. 2012, 24, 4750-4757. [CrossRef]

43. Choi, S.; Cho, Y.G.; Kim, J.; Choi, S.N.; Song, H.K.; Wang, G.; Park, S. Mesoporous Germanium Anode Materials for Lithium-Ion Battery with Exceptional Cycling Stability in Wide Temperature Range. Small 2017, 13, 1603045. [CrossRef] 
44. Chan, C.K.; Zhang, X.F.; Cui, Y. High capacity Li ion battery anodes using Ge nanowires. Nano Lett. 2008, 8, 307-309. [CrossRef]

45. Liu, Z.; Yu, Q.; Zhao, Y.; He, R.; Xu, M.; Feng, S.; Li, S.; Zhou, L.; Mai, L. Silicon oxides: A promising family of anode materials for lithium-ion batteries. Chem. Soc. Rev. 2019, 48, 285-309. [CrossRef]

46. Reddy, M.; Rao, G.S.; Chowdari, B. Metal oxides and oxysalts as anode materials for Li ion batteries. Chem. Rev. 2013, 113, 5364-5457. [CrossRef] [PubMed]

47. Shang, H.; Zuo, Z.; Li, L.; Wang, F.; Liu, H.; Li, Y.; Li, Y. Ultrathin graphdiyne nanosheets grown in situ on copper nanowires and their performance as lithium-ion battery anodes. Angew. Chem. Int. Ed. 2018, 57, 774-778. [CrossRef] [PubMed]

48. Tzadikov, J.; Auinat, M.; Barrio, J.; Volokh, M.; Peng, G.; Gervais, C.; Ein-Eli, Y.; Shalom, M. Layered Boron-Nitrogen-Carbon-Oxygen Materials with Tunable Composition as Lithium-Ion Battery Anodes. ChemSusChem 2018, 11, 2912-2920. [CrossRef]

49. Wang, A.; Kadam, S.; Li, H.; Shi, S.; Qi, Y. Review on modeling of the anode solid electrolyte interphase (SEI) for lithium-ion batteries. npj Comput. Mater. 2018, 4, 1-26. [CrossRef]

50. Julien, C.; Mauger, A.; Vijh, A.; Zaghib, K. Lithium batteries. In Lithium Batteries; Springer: Cham, Switzerland, 2016; pp. 29-68.

51. Arora, P.; Zhang, Z. Battery separators. Chem. Rev. 2004, 104, 4419-4462. [CrossRef]

52. Herle, S.P.; Gordon, J.G. Ceramic Coating on Battery Separators. U.S. Patent No. 10,193,116 B2, 29 January 2019.

53. Shi, C.; Zhang, P.; Chen, L.; Yang, P.; Zhao, J. Effect of a thin ceramic-coating layer on thermal and electrochemical properties of polyethylene separator for lithium-ion batteries. J. Power Sources 2014, 270, 547-553. [CrossRef]

54. Shin, W.-K.; Kim, D.-W. High performance ceramic-coated separators prepared with lithium ion-containing $\mathrm{SiO} 2$ particles for lithium-ion batteries. J. Power Sources 2013, 226, 54-60. [CrossRef]

55. Kim, C.-S.; Yoo, J.-S.; Jeong, K.-M.; Kim, K.; Yi, C.-W. Investigation on internal short circuits of lithium polymer batteries with a ceramic-coated separator during nail penetration. J. Power Sources 2015, 289, 41-49. [CrossRef]

56. Orendorff, C.J. The role of separators in lithium-ion cell safety. Electrochem. Soc. Interface 2012, $21,61$. [CrossRef]

57. Zhang, S.S. A review on the separators of liquid electrolyte Li-ion batteries. J. Power Sources 2007, 164, 351-364. [CrossRef]

58. Li, Z.; Xiong, Y.; Sun, S.; Zhang, L.; Li, S.; Liu, X.; Xu, Z.; Xu, S. Tri-layer nonwoven membrane with shutdown property and high robustness as $a$ high-safety lithium ion battery separator. J. Membr. Sci. 2018, 565, 50-60. [CrossRef]

59. Costa, C.M.; Kundu, M.; Cardoso, V.F.; Machado, A.V.; Silva, M.M.; Lanceros-Méndez, S. Silica/poly(vinylidene fluoride) porous composite membranes for lithium-ion battery separators. J. Membr. Sci. 2018, 564, 842-851. [CrossRef]

60. Sun, G.; Dong, G.; Kong, L.; Yan, X.; Tian, G.; Qi, S.; Wu, D. Robust polyimide nanofibrous membrane with porous-layer-coated morphology by in situ self-bonding and micro-crosslinking for lithium-ion battery separator. Nanoscale 2018, 10, 22439-22447. [CrossRef] [PubMed]

61. Liu, J.; Yang, K.; Mo, Y.; Wang, S.; Han, D.; Xiao, M.; Meng, Y. Highly safe lithium-ion batteries: High strength separator from polyformaldehyde/cellulose nanofibers blend. J. Power Sources 2018, 400, 502-510. [CrossRef]

62. Xu, K. Nonaqueous liquid electrolytes for lithium-based rechargeable batteries. Chem. Rev. 2004, 104, 4303-4418. [CrossRef] [PubMed]

63. Wang, Q.; Sun, J.; Chen, C. Thermal stability of LiPF6/EC + DMC + EMC electrolyte for lithium ion batteries. Rare Metals 2006, 25 (Suppl. 1), 94-99. [CrossRef]

64. Dahbi, M.; Ghamouss, F.; Tran-Van, F.; Lemordant, D.; Anouti, M. Comparative study of EC/DMC LiTFSI and LiPF6 electrolytes for electrochemical storage. J. Power Sources 2011, 196, 9743-9750. [CrossRef]

65. Li, F.; Gong, Y.; Jia, G.; Wang, Q.; Peng, Z.; Fan, W.; Bai, B. A novel dual-salts of LiTFSI and LiODFB in $\mathrm{LiFePO}_{4}$-based batteries for suppressing aluminum corrosion and improving cycling stability. J. Power Sources 2015, 295, 47-54. [CrossRef]

66. Wang, Q.; Jiang, L.; Yu, Y.; Sun, J. Progress of enhancing the safety of lithium ion battery from the electrolyte aspect. Nano Energy 2019, 55, 93-114. [CrossRef] 
67. Zeng, Z.; Wu, B.; Xiao, L.; Jiang, X.; Chen, Y.; Ai, X.; Yang, H.; Cao, Y. Safer lithium ion batteries based on nonflammable electrolyte. J. Power Sources 2015, 279, 6-12. [CrossRef]

68. Xu, K.; Zhang, S.; Allen, J.L.; Jow, T.R. Nonflammable electrolytes for Li-ion batteries based on $a$ fluorinated phosphate. J. Electrochem. Soc. 2002, 149, A1079-A1082. [CrossRef]

69. Zhang, Q.; Noguchi, H.; Wang, H.; Yoshio, M.; Otsuki, M.; Ogino, T. Improved thermal stability of $\mathrm{LiCoO}_{2}$ by cyclotriphosphazene additives in lithium-ion batteries. Chem. Lett. 2005, 34, 1012-1013. [CrossRef]

70. Jiang, L.; Wang, Q.; Sun, J. Electrochemical performance and thermal stability analysis of $\mathrm{LiNi}_{\mathrm{x}} \mathrm{Co}_{\mathrm{y}} \mathrm{Mn}_{\mathrm{z}} \mathrm{O}_{2}$ cathode based on $a$ composite safety electrolyte. J. Hazard. Mater. 2018, 351, 260-269. [CrossRef]

71. Jiang, L.; Wang, Q.; Li, K.; Ping, P.; Jiang, L.; Sun, J. A self-cooling and flame-retardant electrolyte for safer lithium ion batteries. Sustain. Energy Fuels 2018, 2, 1323-1331. [CrossRef]

72. Gogotsi, Y.; Zhao, M.-Q.; Cheng, X.-B. Additives for Suppressing Dendritic Growth in Batteries. U.S. Patent Application No. 16/050,987, 7 February 2019.

73. Ergen, O.; Zettl, A.K. High Temperature Li-Ion Battery Cells Utilizing Boron Nitride Aerogels And Boron Nitride Nanotubes. U.S. Patent Application No. 15/822,563, 16 June 2020.

74. Schmitz, R.; Garsuch, A.; Chesneau, F.F.; Schmidt, M.; Yamamoto, T.; Semrau, G. Overcharge Protection Electrolyte Additive for Lithium Ion Batteries. U.S. Patent No. 10,153,516, 11 December 2018.

75. Lewandowski, A.; Świderska-Mocek, A. Ionic liquids as electrolytes for Li-ion batteries-An overview of electrochemical studies. J. Power Sources 2009, 194, 601-609. [CrossRef]

76. Francis, C.; Louey, R.; Sammut, K.; Best, A.S. Thermal stability of pyrrolidinium-FSI ionic liquid electrolyte and lithium-ion electrodes at elevated temperatures. J. Electrochem. Soc. 2018, 165, A1204. [CrossRef]

77. Moganty, S.; Wu, Y.; Abbate, L.; Brown, K.; Sinicropi, J.; Torres, G. Modified Ionic Liquids Containing Triazine. U.S. Patent Application No. 16/037,902, 17 January 2019.

78. Feng, J.; Ai, X.; Cao, Y.; Yang, H. Possible use of non-flammable phosphonate ethers as pure electrolyte solvent for lithium batteries. J. Power Sources 2008, 177, 194-198. [CrossRef]

79. Feng, J.; Sun, X.; Ai, X.; Cao, Y.; Yang, H. Dimethyl methyl phosphate: A new nonflammable electrolyte solvent for lithium-ion batteries. J. Power Sources 2008, 184, 570-573. [CrossRef]

80. Takechi, K.; Yang, R. Aqueous Electrolyte with Ethers and Batteries Using the Electrolyte. U.S. Patent No. 10,193,188, 29 January 2019.

81. Takechi, K.; Yang, R. Aqueous Electrolytes with Protonic Ionic Liquid and Batteries Using the Electrolyte. U.S. Patent No. 15/663,262, 31 January 2019.

82. Zhu, Y.; Wang, X.; Hou, Y.; Gao, X.; Liu, L.; Wu, Y.; Shimizu, M. A new single-ion polymer electrolyte based on polyvinyl alcohol for lithium ion batteries. Electrochim. Acta 2013,87, 113-118. [CrossRef]

83. Du, Z.; Su, Y.; Qu, Y.; Zhao, L.; Jia, X.; Mo, Y.; Yu, F.; Du, J.; Chen, Y. A mechanically robust, biodegradable and high performance cellulose gel membrane as gel polymer electrolyte of lithium-ion battery. Electrochim. Acta 2019, 299, 19-26. [CrossRef]

84. Zhao, L.; Fu, J.; Du, Z.; Jia, X.; Qu, Y.; Yu, F.; Du, J.; Chen, Y. High-strength and flexible cellulose $>/$ PEG based gel polymer electrolyte with high performance for lithium ion batteries. J. Membr. Sci. 2020, 593, 117428. [CrossRef]

85. Wakihara, M.; Kadoma, Y.; Kumagai, N.; Mita, H.; Araki, R.; Ozawa, K.; Ozawa, Y. Development of nonflammable lithium ion battery using a new all-solid polymer electrolyte. J. Solid State Electrochem. 2012, 16, 847-855. [CrossRef]

86. Youcef, H.B.; Armand, M.; Orayech, B.; Saurel, D.; Shanmukaraj, D. Solid Polymer Electrolyte Based on Modified Cellulose and Its Use in Lithium or Sodium Secondary Batteries. U.S. Patent Application No. 15/663,262, 3 January 2019.

87. Yushin, G.; Turcheniuk, K.; Yiran, X.; Song, A.-Y.; Borodin, O.; Nitta, N. Solid Electrolyte Technology with Rearrangeable Bonds for Metal And Metal-Ion Batteries. U.S. Patent Application No. 16/022,572, 3 January 2019.

88. Spotnitz, R.; Franklin, J. Abuse behavior of high-power, lithium-ion cells. J. Power Sources 2003, 113, 81-100. [CrossRef]

89. Otto, A.; Rzepka, S.; Mager, T.; Michel, B.; Lanciotti, C.; Günther, T.; Kanoun, O. Battery Management Network for Fully Electrical Vehicles Featuring Smart Systems at Cell and Pack Level. In Advanced Microsystems for Automotive Applications; Springer: Berlin/Heidelberg, Germany, 2012; pp. 3-14. 
90. Joachin, H.; Kaun, T.D.; Zaghib, K.; Prakash, J. Electrochemical and Thermal studies of LiFePO4 cathode in lithium-ion cells. ECS Trans. 2008, 6, 11-16. [CrossRef]

91. Yang, H.; Amiruddin, S.; Bang, H.J.; Sun, Y.-K.; Prakash, J. A review of Li-ion cell chemistries and their potential use in hybrid electric vehicles. J. Ind. Eng. Chem. 2006, 12, 12-38.

92. Al-Hallaj, S.; Selman, J.R. Thermal modeling of secondary lithium batteries for electric vehicle/hybrid electric vehicle applications. J. Power Sources 2002, 110, 341-348. [CrossRef]

93. Ruiz, V.; Pfrang, A.; Kriston, A.; Omar, N.; van den Bossche, P.; Boon-Brett, L. A review of international abuse testing standards and regulations for lithium ion batteries in electric and hybrid electric vehicles. Renew. Sustain. Energy Rev. 2018, 81, 1427-1452. [CrossRef]

94. Feng, X.; Ouyang, M.; Liu, X.; Lu, L.; Xia, Y.; He, X. Thermal runaway mechanism of lithium ion battery for electric vehicles: A review. Energy Storage Mater. 2018, 10 (Suppl. C), 246-267. [CrossRef]

95. Larsson, F.; Andersson, P.; Mellander, B.-E. Lithium-ion battery aspects on fires in electrified vehicles on the basis of experimental abuse tests. Batteries 2016, 2, 9. [CrossRef]

96. Lecocq, A.; Bertana, M.; Truchot, B.; Marlair, G. Comparison of the fire consequences of an electric vehicle and an internal combustion engine vehicle. In Proceedings of the International Conference on Fires In Vehicles-FIVE 2012, Chicago, IL, USA, 27-28 September 2012; SP Technical Research Institute of Sweden: Boras, Sweden, 2012.

97. Depetro, A. Future Submarine Fire Safety Study. MSc. Thesis, Victoria University, Melbourne, Australia, 2016.

98. Buckingham, J.; Hodge, C.; Hardy, T. Submarine power and propulsion-application of technology to deliver customer benefit. In Proceedings of the UDT Europe, Glasgow, Scotland, UK, 26-28 June 2008.

99. Spinner, N.S.; Field, C.R.; Hammond, M.H.; Williams, B.A.; Myers, K.M.; Lubrano, A.L.; Rose-Pehrsson, S.L.; Tuttle, S.G. Physical and chemical analysis of lithium-ion battery cell-to-cell failure events inside custom fire chamber. J. Power Sources 2015, 279 (Suppl. C), 713-721. [CrossRef]

100. Lamb, J.; Corendorff, J.; Steele, L.A.M.; Spangler, S.W. Failure propagation in multi-cell lithium ion batteries. J. Power Sources 2015, 283 (Suppl. C), 517-523. [CrossRef]

101. McDowall, J. A guide to lithium-ion battery safety. Battcon 2014, 1, 1-23.

102. Ye, J.; Chen, H.; Wang, Q.; Huang, P.; Sun, J.; Lo, S. Thermal behavior and failure mechanism of lithium ion cells during overcharge under adiabatic conditions. Appl. Energy 2016, 182 (Suppl. C), 464-474. [CrossRef]

103. Yuan, Q.; Zhao, F.; Wang, W.; Zhao, Y.; Liang, Z.; Yan, D. Overcharge failure investigation of lithium-ion batteries. Electrochim. Acta 2015, 178 (Suppl. C), 682-688. [CrossRef]

104. Yamamoto, Y.; Kato, K.; Lin, L.; Fukui, M. A thermal management system for lithium-ion battery in mobile systems. In Proceedings of the European Conference on Circuit Theory and Design (ECCTD), Dresden, Germany, 8-12 September 2013; IEEE: Piscataway, NJ, USA, 2013; pp. 1-4.

105. Li, Z.; Huang, J.; Liaw, B.Y.; Metzler, V.; Zhang, J. A review of lithium deposition in lithium-ion and lithium metal secondary batteries. J. Power Sources 2014, 254 (Suppl. C), 168-182. [CrossRef]

106. Lisbona, D.; Snee, T. A review of hazards associated with primary lithium and lithium-ion batteries. Process Saf. Environ. Prot. 2011, 89, 434-442. [CrossRef]

107. Guo, L.S.; Wang, Z.R.; Wang, J.H.; Luo, Q.K.; Liu, J.J. Effects of the environmental temperature and heat dissipation condition on the thermal runaway of lithium ion batteries during the charge-discharge process. J. Loss Prev. Process Ind. 2017, 49, 953-960. [CrossRef]

108. Yang, H.; Bang, H.; Amine, K.; Prakash, J. Investigations of the exothermic reactions of natural graphite anode for Li-ion batteries during thermal runaway. J. Electrochem. Soc. 2005, 152, A73-A79. [CrossRef]

109. Lee, C.W.; Venkatachalapathy, R.; Prakash, J. A Novel Flame-Retardant Additive for Lithium Batteries. Electrochem. Solid-State Lett. 2000, 3, 63-65. Electrochem. Solid-State Lett. 2000, 3, 63-65. [CrossRef]

110. Lamb, J.; Orendorff, C.J. Evaluation of mechanical abuse techniques in lithium ion batteries. J. Power Sources 2014, 247 (Suppl. C), 189-196. [CrossRef]

111. Wang, Q.; Ping, P.; Zhao, X.; Chu, G.; Sun, J.; Chen, C. Thermal runaway caused fire and explosion of lithium ion battery. J. Power Sources 2012, 208 (Suppl. C), 210-224. [CrossRef]

112. Ribière, P.; Grugeon, S.; Morcrette, M.; Boyanov, S.; Laruelle, S.; Marlair, G. Investigation on the fire-induced hazards of Li-ion battery cells by fire calorimetry. Energy Environ. Sci. 2012, 5, 5271-5280. [CrossRef]

113. Ping, P.; Wang, Q.; Huang, P.; Li, K.; Sun, J.; Kong, D.; Chen, C. Study of the fire behavior of high-energy lithium-ion batteries with full-scale burning test. J. Power Sources 2015, 285 (Suppl. C), 80-89. [CrossRef] 
114. MacNeil, D.; Lu, Z.; Chen, Z.; Dahn, J.R. A comparison of the electrode/electrolyte reaction at elevated temperatures for various Li-ion battery cathodes. J. Power Sources 2002, 108, 8-14. [CrossRef]

115. Zheng, W. GB/T 31485 Translated English of Chinese Standard, Safety Requirements and Test Methods for Traction Battery of Electric Vehicle; ICS: Amsterdam, The Netherlnads, 2015; p. 17.

116. Wilkens, K.; Johnsen, B.; Bhargava, A.; Dragsted, A. Assessment of Existing Fire Protection Strategies and Recommendation for Future Work, in Project BLUE BATTERY, Part II; Danish Institute of Fire and security Technolog: Hvidovre, Denmark, 2017.

117. Liu, K.; Liu, Y.; Lin, D.; Pei, A.; Cui, Y. Materials for lithium-ion battery safety. Sci. Adv. 2018, 4, eaas9820. [CrossRef] [PubMed]

118. Wang, Q.; Mao, B.; Stoliarov, S.I.; Sun, J. A review of lithium ion battery failure mechanisms and fire prevention strategies. Prog. Energy Combust. Sci. 2019, 73, 95-131. [CrossRef]

119. Li, J.; Zhang, Q.; Liu, C.; He, X. ZrO $\mathrm{Zr}_{2}$ coating of $\mathrm{LiNi}_{1 / 3} \mathrm{Co}_{1 / 3} \mathrm{Mn}_{1 / 3} \mathrm{O}_{2}$ cathode materials for Li-ion batteries. Ionics 2009, 15, 493-496. [CrossRef]

120. Kannan, A.M.; Manthiram, A. Surface/chemically modified $\mathrm{LiMn}_{2} \mathrm{O}_{4}$ cathodes for lithium-ion batteries. Electrochem. Solid-State Lett. 2002, 5, A167-A169. [CrossRef]

121. Love, C.T.; Johannes, M.D.; Swider-Lyons, K. Thermal Stability of Delithiated Al-substituted $\mathrm{Li}\left(\mathrm{Ni}_{1 / 3} \mathrm{Co}_{1 / 3}\right.$ $\left.\mathrm{Mn}_{1 / 3}\right) \mathrm{O}_{2}$ Cathodes. ECS Trans. 2010, 25, 231. [CrossRef]

122. Zhou, F.; Zhao, X.; Jiang, J.; Dahn, J. Advantages of Simultaneous Substitution of Co in $\operatorname{Li}\left[\mathrm{Ni}_{1 / 3} \mathrm{Mn}_{1 / 3} \mathrm{Co}_{1 / 3}\right]$ $\mathrm{O}_{2}$ by $\mathrm{Ni}$ and Al. Electrochem. Solid-State Lett. 2009, 12, A81-A83.

123. Liu, S.; Dang, Z.; Liu, D.; Zhang, C.; Huang, T.; Yu, A. Comparative studies of zirconium doping and coating on LiNi0. 6Co0. 2Mn0. $2 \mathrm{O} 2$ cathode material at elevated temperatures. J. Power Sources 2018, 396, 288-296.

124. Yang, L.; Ren, F.; Feng, Q.; Xu, G.; Li, X.; Li, Y.; Zhao, E.; Ma, J.; Fan, S. Effect of Cu doping on the structural and electrochemical performance of $\mathrm{LiNi}_{1 / 3} \mathrm{Co}_{1 / 3} \mathrm{Mn}_{1 / 3} \mathrm{O}_{2}$ cathode materials. J. Electron. Mater. 2018, 47, 3996-4002. [CrossRef]

125. Liu, H. Lithium Ion Battery and Positive Active Material Thereof. U.S. Patent Application No. 16/045,723, 31 January 2019.

126. Chaoyi, Z.; Zhu'an, Y.; Wang, L.; Daixiang, Y.; Peng, P.; Xiang, Q.; Mei, M.; Li, L. Spherical or Spherical-Like Cathode Material for Lithium-Ion Battery and Lithium-Ion Battery. U.S. Patent Application No. 16/022,757, 17 January 2019.

127. Chaoyi, Z.; Wang, L.; Zhu'an, Y.; Daixiang, Y.; Xiang, Q.; Mei, M.; Peng, P. Spherical or Spherical-Like Cathode Material for a Lithium Battery, a Battery and Preparation Method and Application Thereof. U.S. Patent No. 16/751,337, 21 May 2020.

128. Jung, Y.S.; Cavanagh, A.S.; Riley, L.A.; Kang, S.H.; Dillon, A.C.; Groner, M.D.; George, S.M.; Lee, S.H. Ultrathin direct atomic layer deposition on composite electrodes for highly durable and safe Li-ion batteries. Adv. Mater. 2010, 22, 2172-2176. [CrossRef] [PubMed]

129. Drews, A.R.; Anandan, V. Electrode design to improve li-ion battery safety. U.S. Patent Application No 15/668,876, 7 February 2019.

130. Xu, W.; Wang, J.; Ding, F.; Chen, X.; Nasybulin, E.; Zhang, Y.; Zhang, J.-G. Lithium metal anodes for rechargeable batteries. Energy Environ. Sci. 2014, 7, 513-537. [CrossRef]

131. Lin, D.; Liu, Y.; Cui, Y. Reviving the lithium metal anode for high-energy batteries. Nat. Nanotechnol. 2017, 12, 194. [CrossRef]

132. Cao, X.; Li, Y.; Li, X.; Zheng, J.; Gao, J.; Gao, Y.; Wu, X.; Zhao, Y.; Yang, Y. Novel phosphamide additive to improve thermal stability of solid electrolyte interphase on graphite anode in lithium-ion batteries. ACS Appl. Mater. Interfaces 2013, 5, 11494-11497. [CrossRef]

133. Boukamp, B.; Lesh, G.; Huggins, R. All-solid lithium electrodes with mixed-conductor matrix. J. Electrochem. Soc. 1981, 128, 725. [CrossRef]

134. Chan, C.K.; Peng, H.; Liu, G.; McIlwrath, K.; Zhang, X.F.; Huggins, R.A.; Cui, Y. High-performance lithium battery anodes using silicon nanowires. Nat. Nanotechnol. 2008, 3, 31. [CrossRef]

135. Belharouak, I.; Koenig, G.M., Jr.; Amine, K. Electrochemistry and safety of Li4Ti5O12 and graphite anodes paired with LiMn2O4 for hybrid electric vehicle Li-ion battery applications. J. Power Sources 2011, 196, 10344-10350. [CrossRef] 
136. Feng, X.; Sun, J.; Ouyang, M.; Wang, F.; He, X.; Lu, L.; Peng, H. Characterization of penetration induced thermal runaway propagation process within a large format lithium ion battery module. J. Power Sources 2015, 275, 261-273. [CrossRef]

137. Park, C.-K. Nonaqueous Electrolyte for Lithium Battery Safety. U.S. Patent No. 10,038,220, 31 July 2018.

138. Wang, Q.; Sun, J.; Chen, C. Effects of solvents and salt on the thermal stability of lithiated graphite used in lithium ion battery. J. Hazard. Mater. 2009, 167, 1209-1214. [CrossRef] [PubMed]

139. Wang, Q.; Sun, J.; Chen, X.; Chu, G.; Chen, C. Effects of solvents and salt on the thermal stability of charged LiCoO2. Mater. Res. Bull. 2009, 44, 543-548. [CrossRef]

140. Jiang, J.; Dahn, J. Effects of solvents and salts on the thermal stability of LiC6. Electrochim. Acta 2004, 49, 4599-4604. [CrossRef]

141. Xu, W.; Deng, Z.; Bolomey, P. Stabilized Nonaqueous Electrolytes for Rechargeable Batteries. U.S. Patent No. 7,638,243, 29 December 2009.

142. Guerfi, A.; Duchesne, S.; Kobayashi, Y.; Vijh, A.; Zaghib, K. LiFePO4 and graphite electrodes with ionic liquids based on bis (fluorosulfonyl)imide (FSI) - for Li-ion batteries. J. Power Sources 2008, 175, 866-873. [CrossRef]

143. Prakash, J.; Lee, C.W.; Amine, K. Flame-retardant additive for Li-ion batteries. U.S. Patent No. 6,455,200, 24 September 2002.

144. Yao, X.; Xie, S.; Chen, C.; Wang, Q.; Sun, J.; Li, Y.; Lu, S. Comparative study of trimethyl phosphite and trimethyl phosphate as electrolyte additives in lithium ion batteries. J. Power Sources 2005, 144, 170-175. [CrossRef]

145. Lee, H.-H.; Wang, Y.-Y.; Wan, C.-C.; Yang, M.-H.; Wu, H.-C.; Shieh, D.-T. The function of vinylene carbonate as $a$ thermal additive to electrolyte in lithium batteries. J. Appl. Electrochem. 2005, 35, 615-623. [CrossRef]

146. Xia, L.; Wang, D.; Yang, H.; Cao, Y.; Ai, X. An electrolyte additive for thermal shutdown protection of Li-ion batteries. Electrochem. Commun. 2012, 25, 98-100. [CrossRef]

147. Tsujikawa, T.; Yabuta, K.; Matsushita, T.; Matsushima, T.; Hayashi, K.; Arakawa, M. Characteristics of lithium-ion battery with non-flammable electrolyte. J. Power Sources 2009, 189, 429-434. [CrossRef]

148. Balakrishnan, P.; Ramesh, R.; Kumar, T.P. Safety mechanisms in lithium-ion batteries. J. Power Sources 2006, 155, 401-414. [CrossRef]

149. Yeh, S.-F. Actuating Structure of Battery Safety Valve. U.S. Patent No. 10,103,371, 16 October 2018.

150. Cherng, J.-Y.; Pin-Shiuan, L.; Cheng, T.-T. Lithium Battery with Exhaust Structure. U.S. Patent No. 10,121,998, 6 November 2018.

151. Coman, P.T.; Rayman, S.; White, R.E. A lumped model of venting during thermal runaway in $a$ cylindrical Lithium Cobalt Oxide lithium-ion cell. J. Power Sources 2016, 307, 56-62. [CrossRef]

152. Finegan, D.P. X-Ray Imaging of Failure and Degradation Mechanisms of Lithium-Ion Batteries. Ph.D. Thesis, UCL (University College London), London, UK, 2016.

153. Doughty, D.H.; Roth, E.P. A general discussion of Li ion battery safety. Electrochem. Soc. Interface 2012, 21, 37-44.

154. Lu, L.; Han, X.; Li, J.; Hua, J.; Ouyang, M. A review on the key issues for lithium-ion battery management in electric vehicles. J. Power Sources 2013, 226, 272-288. [CrossRef]

155. Wei, Z.; Meng, S.; Xiong, B.; Ji, D.; Tseng, K.J. Enhanced online model identification and state of charge estimation for lithium-ion battery with a FBCRLS based observer. Appl. Energy 2016, 181, 332-341. [CrossRef]

156. Wei, Z.; Zhao, J.; Ji, D.; Tseng, K.J. A multi-timescale estimator for battery state of charge and capacity dual estimation based on an online identified model. Appl. Energy 2017, 204, 1264-1274. [CrossRef]

157. Xiong, B.; Zhao, J.; Su, Y.; Wei, Z.; Skyllas-Kazacos, M. State of charge estimation of vanadium redox flow battery based on sliding mode observer and dynamic model including capacity fading factor. IEEE Trans. Sustain. Energy 2017, 8, 1658-1667. [CrossRef]

158. Dong, G.; Yang, F.; Wei, Z.; Wei, J.; Tsui, K.-L. Data-driven battery health prognosis using adaptive Brownian motion model. IEEE Trans. Ind. Inform. 2019, 16, 4736-4746. [CrossRef]

159. Liu, K.; Hu, X.; Wei, Z.; Li, Y.; Jiang, Y. Modified Gaussian process regression models for cyclic capacity prediction of lithium-ion batteries. IEEE Trans. Transp. Electrif. 2019, 5, 1225-1236. [CrossRef] 
160. Kim, T.; Adhikaree, A.; Pandey, R.; Kang, D.; Kim, M.; Oh, C.-Y.; Back, J. Outlier mining-based fault diagnosis for multiceli lithium-ion batteries using a low-priced microcontroller. In Proceedings of the 2018 IEEE Applied Power Electronics Conference and Exposition (APEC), San Antonio, TX, USA, 4-8 March 2018; IEEE: Piscataway, NJ, USA, 2018; pp. 3365-3369.

161. Feng, X.; Weng, C.; Ouyang, M.; Sun, J. Online internal short circuit detection for $a$ large format lithium ion battery. Appl. Energy 2016, 161, 168-180. [CrossRef]

162. Wei, Z.; Dong, G.; Zhang, X.; Pou, J.; Quan, Z.; He, H. Noise-immune model identification and state of charge estimation for lithium-ion battery using bilinear parameterization. IEEE Trans. Ind. Electron. 2020, 1, 1-19. [CrossRef]

163. Wei, Z.; Zhao, D.; He, H.; Cao, W.; Dong, G. A noise-tolerant model parameterization method for lithium-ion battery management system. Appl. Energy 2020, 268, 114932. [CrossRef]

164. Zou, C.; Klintberg, A.; Wei, Z.; Fridholm, B.; Wik, T.; Egardt, B. Power capability prediction for lithium-ion batteries using economic nonlinear model predictive control. J. Power Sources 2018, 396, 580-589. [CrossRef]

165. Yan, J.; Wang, Q.; Li, K.; Sun, J. Numerical study on the thermal performance of $a$ composite board in battery thermal management system. Appl. Therm. Eng. 2016, 106, 131-140. [CrossRef]

166. Ye, Y.; Saw, L.H.; Shi, Y.; Tay, A.A. Numerical analyses on optimizing $a$ heat pipe thermal management system for lithium-ion batteries during fast charging. Appl. Therm. Eng. 2015, 86, 281-291. [CrossRef]

167. Zhai, H.; Cui, X. Thermal Management System. U.S. Patent Application No. 16/044,708, 31 January 2019.

168. Coleman, B.; Ostanek, J.; Heinzel, J. Reducing cell-to-cell spacing for large-format lithium ion battery modules with aluminum or PCM heat sinks under failure conditions. Appl. Energy 2016, 180, 14-26. [CrossRef]

169. Fan, L.; Khodadadi, J.; Pesaran, A. A parametric study on thermal management of an air-cooled lithium-ion battery module for plug-in hybrid electric vehicles. J. Power Sources 2013, 238, 301-312. [CrossRef]

170. Chen, K.; Wang, S.; Song, M.; Chen, L. Structure optimization of parallel air-ccooled battery thermal management system. Int. J. Heat Mass Transf. 2017, 111, 943-952. [CrossRef]

171. Mahamud, R.; Park, C. Reciprocating air flow for Li-ion battery thermal management to improve temperature uniformity. J. Power Sources 2011, 196, 5685-5696. [CrossRef]

172. Yu, K.; Yang, X.; Cheng, Y.; Li, C. Thermal analysis and two-directional air flow thermal management for lithium-ion battery pack. J. Power Sources 2014, 270, 193-200. [CrossRef]

173. Yang, N.; Zhang, X.; Li, G.; Hua, D. Assessment of the forced air-cooling performance for cylindrical lithium-ion battery packs: A comparative analysis between aligned and staggered cell arrangements. Appl. Therm. Eng. 2015, 80, 55-65. [CrossRef]

174. Zhao, J.; Rao, Z.; Li, Y. Thermal performance of mini-channel liquid cooled cylinder based battery thermal management for cylindrical lithium-ion power battery. Energy Convers. Manag. 2015, 103, 157-165. [CrossRef]

175. Karimi, G.; Dehghan, A. Thermal analysis of high-power lithium-ion battery packs using flow network approach. Int. J. Energy Res. 2014, 38, 1793-1811. [CrossRef]

176. Kizilel, R.; Sabbah, R.; Selman, J.R.; Al-Hallaj, S. An alternative cooling system to enhance the safety of Li-ion battery packs. J. Power Sources 2009, 194, 1105-1112. [CrossRef]

177. Al Hallaj, S.; Selman, J. A novel thermal management system for electric vehicle batteries using phase-change material. J. Electrochem. Soc. 2000, 147, 3231-3236. [CrossRef]

178. Bustamante, J.G.; Sole, J.D. Internal Battery Cell Cooling with Heat Pipe. U.S. Patent Application No. 15/132,668, 29 January 2019.

179. Weng, Y.-C.; Cho, H.-P.; Chang, C.-C.; Chen, S.-L. Heat pipe with PCM for electronic cooling. Appl. Energy 2011, 88, 1825-1833. [CrossRef]

180. Yu, M.G.; Wang, S.H.; Hu, X.F. Heat transfer capacity of composite cooling system for automobile lithium-ion battery with heat pipe and phase change materials. Adv. Mater. Res. 2014, 941, 2469-2473. [CrossRef]

181. National Fire Protection Association. NFPA 13, Standard for the Installation of Sprinkler Systems; National Fire Protection Association: Quincy, MS, USA, 2002.

182. Liu, Z.; Kim, A.K.; Carpenter, D. A study of portable water mist fire extinguishers used for extinguishment of multiple fire types. Fire Saf. J. 2007, 42, 25-42. [CrossRef]

183. Watanabe, N.; Sugawa, O.; Suwa, T.; Ogawa, Y.; Hiramatsu, M.; Hino, T.; Miyamoto, H.; Okamoto, K.; Honma, M. Comparison of fire behaviors of an electric-battery-powered vehicle and gasoline-powered vehicle in a real-scale fire test. In Proceedings of the 2nd International Conference on Fires in Vehicles-FIVE, Chicago, IL, USA, 27-28 September 2012. 
184. Ouyang, D.; Chen, M.; Huang, Q.; Weng, J.; Wang, Z.; Wang, J. A Review on the Thermal Hazards of the Lithium-Ion Battery and the Corresponding Countermeasures. Appl. Sci. 2019, 9, 2483. [CrossRef]

185. Reif, R.H.; Liffers, M.; Forrester, N.; Peal, K. Lithium Battery Safety. Prof. Safety 2010, 55, 32.

186. Farrington, M.D. Safety of lithium batteries in transportation. J. Power Sources 2001, 96, 260-265. [CrossRef]

187. Larsson, F. Lithium-Ion Battery Safety-Assessment by Abuse Testing, Fluoride Gas Emissions And Fire Propagation. Ph.D. Thesis, Chalmers University of Technology, Göteborg, Sweden, 2017.

188. Wang, Q.; Li, K.; Wang, Y.; Chen, H.; Duan, Q.; Sun, J. The efficiency of dodecafluoro-2-methylpentan-3-one on suppressing the lithium ion battery fire. J. Electrochem. Energy Convers. Storage 2018, 15(4), 41-51. [CrossRef]

189. Beitland, S.; Stokland, O.; Skaug, V.; Skogstad, A.; Klingenberg, O. Inhalation of fire extinguisher powder. Eur. J. Trauma 2006, 32, 286-291. [CrossRef]

190. Jiang, Z.; Chow, W.; Li, S. Review on additives for new clean fire suppressants. Environ. Eng. Sci. 2007, 24, 663-674. [CrossRef]

191. Gann, R.G.; Burgess, S.R.; Whisner, K.C.; Reneke, P.A. Preface to the Cumulative Proceedings of the First 14 Halon Options Technical Working Conferences; NIST Pubs: Gaithersburg, MD, USA, 20 May 2017.

192. Benson, C.; Fernando-Cerezo, G.; Holborn, P.; Mba, D. Fire suppression systems in aircraft: Their past, present \& future. Fire Investig. 2016, 1, 34-41.

193. Summer, S.M. Flammability Assessment of Lithium-Ion and Lithium-Ion Polymer Battery Cells Designed for Aircraft Power Usage; US Department of Transportation, Federal Aviation Administration: Washington, DC, USA, 2010.

194. Ditch, B.; de Vries, J. Flammability Characterization of Lithium-ion Batteries in Bulk Storage; FM Global: Norwood, MA, USA, 20 March 2013.

195. Webster, H. Flammability Assessment of Bulk-Packed, Rechargeable Lithium-Ion Cells in Transport Category Aircraft; Office of Aviation Research, Federal Aviation Administration: Washington, DC, USA, 2006.

196. Rao, H.; Huang, Z.; Zhang, H.; Xiao, S. Study of fire tests and fire safety measures on lithiumion battery used on ships. In Proceedings of the 2015 International Conference on Transportation Information and Safety (ICTIS), Wuhan, China, 25-28 June 2015; IEEE: Piscataway, NJ, USA, 2015; pp. 865-870.

197. Wang, Q.; Shao, G.; Duan, Q.; Chen, M.; Li, Y.; Wu, K.; Liu, B.; Peng, P.; Sun, J. The efficiency of heptafluoropropane fire extinguishing agent on suppressing the lithium titanate battery fire. Fire Technol. 2016, 52, 387-396. [CrossRef]

198. Liu, Y.; Duan, Q.; Xu, J.; Chen, H.; Lu, W.; Wang, Q. Experimental study on the efficiency of dodecafluoro-2-methylpentan-3-one on suppressing lithium-ion battery fires. Rsc Adv. 2018, 8, 42223-42232. [CrossRef]

199. Hill, D. Considerations for Energy Storage Systems (ESS) Fire Safety; DET NORSKE VERITAS (U.S.A.); INC: Dublin, OH, USA, 2017.

200. Egelhaaf, M.; Kress, D.; Wolpert, D.; Lange, T.; Justen, R.; Wilstermann, H. Fire Fighting of Li-Ion Traction Batteries. Sae Int. J. Altern. Powertrains 2013, 2, 37-48. [CrossRef]

201. Maloney, T. Extinguishment of Lithium-Ion and Lithium-Metal Battery Fires; US Federal Aviation Administration: Washington, DC, USA, 2014; pp. 46-51.

202. Larsson, F.; Andersson, P.; Blomqvist, P.; Lorén, A.; Mellander, B.-E. Characteristics of lithium-ion batteries during fire tests. J. Power Sources 2014, 271, 414-420. [CrossRef]

203. Andersson, P.; Arvidson, M.; Evegren, F.; Jandali, M.; Larsson, F.; Rosengren, M. Lion Fire: Extinguishment and mitigation of fires in Li-ion batteries at sea. DiVA 2018, 49, 49.

204. Zhu, M.-X.; Zhu, S.-B.; Gong, J.-H.; Zhou, Z. Experimental Study on Fire and Explosion Characteristics of Power Lithium Batteries with Surfactant Water Mist. Procedia Eng. 2018, 211, 1083-1090. [CrossRef]

205. Zhang, Q.; Cao, W.; Bai, W. Experimental study on inhibition effect of water mist on thermal runaway of lithium ion batteries. Fire Saf. Sci. 2017, 4, 8 .

206. Long, R.T.; Blum, A.F.; Bress, T.J.; Cotts, B.R. Best Practices for Emergency Response to Incidents Involving Electric Vehicles Battery Hazards: A Report on Full-Scale Testing Results; National Fire Protection Research Foundation: Quincy, MA, USA, 2013.

207. Luo, W.-T.; Zhu, S.-B.; Gong, J.-H.; Zhou, Z. Research and development of fire extinguishing technology for power lithium batteries. Procedia Eng. 2018, 211, 531-537. [CrossRef]

208. Li, Y.; Yu, D.; Zhang, S.; Hu, Q.; Liu, X.; Wang, J. On the fire extinguishing tests of typical lithium ion battery. J. Saf. Environ. 2015, 15, 120-125.

209. Lefebvre, A.H.; McDonell, V.G. Atomization and Sprays; CRC Press: Boca Raton, FL, USA, 2017. 
210. Mawhinney, J.R.; Back, G.G., III. Water mist fire suppression systems. In SFPE Handbook of Fire Protection Engineering; Springer: New York, NY, USA, 2016; pp. 1587-1645.

211. National Fire Protection Association. NFPA 750 Standard for Water Mist Fire Suppression Systems; NFPA: Quincy, MA, USA, 2010.

212. Braidech, M.; Neale, J.; Matson, A.; Dufour, R. The Mechanism of Extinguishment of Fire By Finely Divided Water; Underwriters Laboratories Inc. for the National Board of Fire Underwriters; National Board of Fire Underwriters: New York, NY, USA, 1955; p. 73.

213. Rasbash, D.; Rogowski, Z.; Stark, G. Mechanisms of extinction of liquid fires with water sprays. Combust. Flame 1960, 4, 223-234. [CrossRef]

214. Baumgarten, C. Mixture Formation in Internal Combustion Engines; Springer Science \& Business Media: Berlin, Germany, 2006.

215. Mawhinney, J.; Dlugogorski, B.; Kim, A. A closer look at the fire extinguishing properties of water mist. Fire Saf. Sci. 1994, 4, 47-60. [CrossRef]

216. Mahmud, H. Simulation of the Suppression of Fires Using Water Mists. Ph.D. Thesis, Victoria University, Melbourne, Australia, 2016.

217. Back, G.G., III; Beyler, C.L.; Hansen, R. A quasi-steady-state model for predicting fire suppression in spaces protected by water mist systems. Fire Saf. J. 2000, 35, 327-362. [CrossRef]

218. Dembele, S.; Wen, J.; Sacadura, J.-F. Experimental study of water sprays for the attenuation of fire thermal radiation. J. Heat Transf. 2001, 123, 534-543. [CrossRef]

219. Liu, Z.; Kim, A.; Su, J. Improvement of efficacy of water mist in fire suppression by cycling discharges. Second International Conference on Fire Research and Engineering, Gaithersburg, MD, USA, 3-8 August 1997; pp. 275-281.

220. Liu, Z.; Kim, A.K. A review of water mist fire suppression systems-fundamental studies. J. Fire Prot. Eng. 1999, 10, 32-50.

221. British Standards Institution. BS 8489 Fixed Fire Protection Systems. Industrial and Commercial Watermist Systems. Code of Practice for Design and Installation; British Standards Institution: London, UK, 2016.

222. National Standards Authority of Ireland. SR CEN/TS 14972Fixed Firefighting Systems-Watermist Systems_Design and Installation; National Standards Authority of Ireland: Dublin, Ireland, 2011.

(C) 2020 by the authors. Licensee MDPI, Basel, Switzerland. This article is an open access article distributed under the terms and conditions of the Creative Commons Attribution (CC BY) license (http://creativecommons.org/licenses/by/4.0/). 